\title{
Drug-induced Hepatotoxicity and Hepatoprotective Medicinal Plants: A Review
}

\author{
Arvind Kumar Shakya* \\ Department of School of Sciences, Biochemistry Discipline, Indira Gandhi National Open University, New Delhi, INDIA.
}

\begin{abstract}
The Liver, a paramount organ is the Chief site for metabolism of nutrients and energy production in the human body. It is also necessary for metabolism and elimination of exogenous drugs and harmful substances via kidney. Hepatotoxicity caused by a variety of environmental pollutants, pathogenic micro-organism, viruses, drugs and chemical agents may account for various hepatic diseases such as jaundice, necrosis, hepatitis, fibrosis and cirrhosis etc. Ayurveda is a traditional medicinal system of India and is being practiced continuously since ancient times and at present for the treatment of various human diseases. Medicinal plants as a significant source of therapeutic compounds used for the development of effective drugs against a variety of human diseases include liver ailments. Hence, therapeutic plants are becoming popular in the pharmaceutical industry to develop a safe and effective medicine for the treatment of the emerging new human diseases. Therefore, the present review is aimed to compiling data on hepatoprotective medicinal plants which have been investigated against drug-induced hepatotoxicity.
\end{abstract}

Key words: Medicinal Plants, Carbon tetrachloride, Paracetamol, Alcohol, Hepatotoxicity, Hepatoprotection.

\section{INTRODUCTION}

Liver is the principal and metabolic organ involved in the metabolism of vital molecules. Besides the metabolic role, it plays a central role in detoxification and excretion of endogenous and exogenous compounds thereby protecting body from the harmful substances. ${ }^{1}$ In this process, the liver injury occurs due to prolonged exposure with xenobiotics and their metabolites. ${ }^{2}$ Liver is also involved with almost all the biochemical pathways of growth, fight against diseases, nutrient supply and energy metabolism. Liver stands out from rest of the organs due to its regenerative property in response to liver damage. ${ }^{3}$ Apart from the drugs (paracetamol, antibiotic, antituberculosis and chemotherapeutic drugs), there are various other chemicals account for liver injury including alcohol consumption, heavy metals used in industries like lead, arsenic etc (Figure 1) ${ }^{4,5}$ Chemical induced hepatotoxicity has been extensively studied in animal model and the changes in biochemical pathways in association with pathological progress in the liver have been well documented. ${ }^{6,7}$ Hepatic damage results in necrosis, jaundice, fibrosis, cirrhosis, hepatitis, liver carcinoma etc. ${ }^{8}$ Liver diseases are one of the leading causes of illness and death globally. According to WHO estimates about 1.4 million deaths worldwide are due to the liver diseases. Although, modern medicine may treat to hepatic diseases, but they also cause numerous side effects in the human body. ${ }^{9}$

In the Ayurvedic system of Indian medicine, people used medicinal plants for centuries to manage the primary health care need. Plant-based therapy still rely for the prevention and treatment of health related problems for thousands years including liver diseases. ${ }^{10}$ Conventional medicine is now pursuing the use of natural products such as herbs to provide the support that
Submission Date: 28-09-2019; Revision Date: 23-12-2019; Accepted Date: 24-01-2020

DOI: 10.5530/ijper.54.2.28 Correspondence: Dr. Arvind Kumar Shakya, Assistant Professor, Department of School of Sciences, Biochemistry Discipline, Indira Gandhi National Open University, New Delhi 110068, INDIA Phone: +91 8447106178

E-mail: arvind.kumar@ignou. ac.in

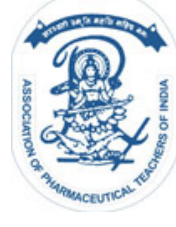

www.ijper.org 


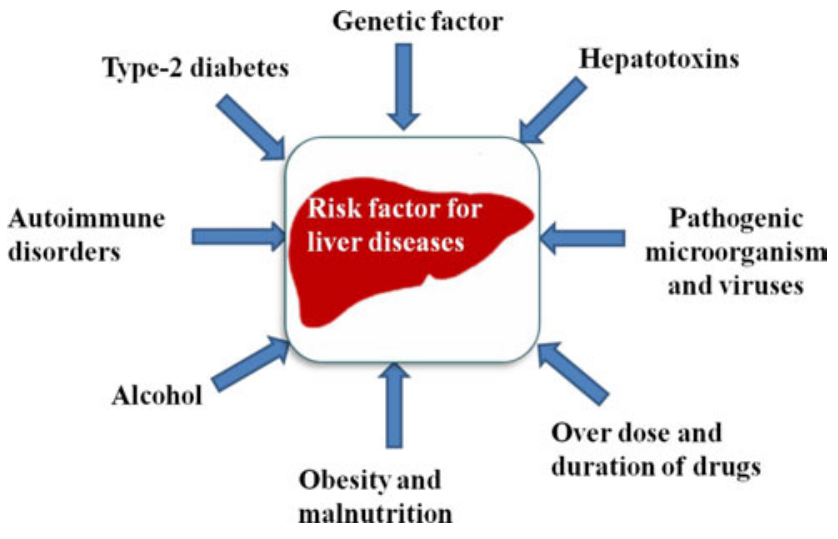

Figure 1: Possible risk factor for development of liver diseases.

the liver needs on a daily basis. ${ }^{11}$ Therefore, it is essential to explore the suitable herbal drugs that could replace the chemical ones.

Indian medicinal plants also provide a rich source for antioxidants that are known to prevent different diseased states. The antioxidant protection is observed at different levels. The medicinal plants also contain other beneficial compounds like phytochemical ingredients for functional foods. Hence, the global knowledge about Ayurveda and Indian herbals will hopefully be enhanced by information on the evidence-base of these plants. This will yield rich dividends in the coming years. Plants with medicinal properties are considered as more reliable and efficient options and also reported to be used traditionally to treat liver ailments. Many traditional plants are being used traditionally to cure various ailments in rural and tribal villages in India. ${ }^{12}$ Majorly plant-based preparations have been used to treat liver disorders. Herbal compounds perform natural process of healing in the human body. There has been a shift in universal trend from synthetic to herbal medicines for the prevention of diseases and ailments. The World Health Organization [WHO] estimates that 4 billion people use herbal medicines for some aspect of primary healthcare. ${ }^{13,14}$ A large experimental work is now being done on ethnopharmacology of herbal medicines. Search of new herbal drugs with better potential of healing and high safety profile is the current area of research interest. Numerous medicinal plants and their bioactive compounds have been studied and found to have hepatoprotective property against various types of drug-induced hepatotoxicity (Table 1,2) and this review mainly summarized the drug-induced hepatotoxicity and hepatoprotective medicinal plants which have been evaluated in vivo and in vitro model.

\section{Model Hepatotoxicants}

\section{Acetaminophen (Paracetamol)}

Acetaminophen also known as paracetamol or $\mathrm{N}$-acetyl$p$ - aminophenol [APAP]. A safe and effective analgesic and antipyretic drug under recommended. ${ }^{15,16}$ Recommended dosage of APAP ranges 325-650 mg every 4-6 hr in adults with a maximum of $4 \mathrm{~g}$ a day and $10-15 \mathrm{mg} / \mathrm{kg}$ every 4-6 hr with maximum of $50-75 \mathrm{mg} / \mathrm{kg}$ in children. ${ }^{17,18}$ Under therapeutic dosage, APAP is generally metabolized in the liver (5-9\%) by Cytochrome P-450 enzyme system into the reactive metabolite called $\mathrm{N}$-acetyl-p-benzo-quinoneimine (NAPQI) but majority 80-90\% was metabolised via phase II metabolic pathway (glucuronidation and sulfation) in which APAPreduced glutathione (GSH]) conjugate is catalyzed by UDP-glucuronosyl transferases (UGT) and sulfotransferase (SULT), into non-toxic compounds: glucouronidated and sulfated metabolites which are eliminated through urine (Figure 2). Although, APAP's consumption for longer days may potentially harmful to the liver. ${ }^{19}$ Because NAPQI metabolite is produced in excess amount which caused lipid peroxidation and it may bind to cellular proteins forming protein adducts resulting in depletion of metabolic energy (adenosine triphosphate, ATP) and cell necrosis. ${ }^{20}$ The APAP hepatotoxicity is the classical example of direct liver injury which can cause acute and severe liver injury in both human and experimental animals. ${ }^{21}$

APAP hepatotoxicity is currently the single most important cause for acute liver failure worldwide and is associated with significant number of deaths. ${ }^{22}$ Metabolic toxicity of APAP has been well studied in humans and experimental animals. ${ }^{23}$ More than 50\% of all cases of acute liver failure in the United States from 1997 to 2002 have been shown to result from exposure to drugs and $40 \%$ of these have been attributed to acetaminophen ingestion. ${ }^{24}$ It has been studied that hepatotoxicity occurs following ingestion of a single

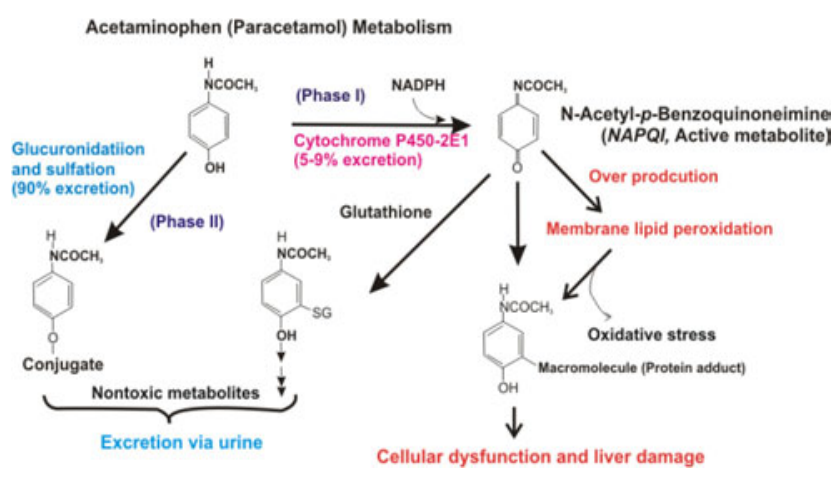

Figure 2: Metabolism of Acetaminophen with the hepatotoxicity. 


\section{Table 1: List of few hepatoprotective medicinal plants against toxic chemical induced liver damage in} experimental animals.

\begin{tabular}{|c|c|c|c|}
\hline Medicinal Plants & Part used & Hepatotoxicants & Biochemical Parameters studied for hepatoprotection \\
\hline Sida acuta ${ }^{157}$ & Root & APAP & Hexobarbitone, in vitro LPO and histopathology \\
\hline Sphaeranthus indicus ${ }^{158}$ & Flower head & APAP & $\begin{array}{c}\text { AST, ALT, ACP, SALP, bilirubin, protein, LPO, SOD, CAT and GPX, } \\
\text { Histology }\end{array}$ \\
\hline Clausena dentata $a^{159}$ & Stem bark & APAP & AST, ALT, ALP, total bilirubin, GGTP and protein \\
\hline Cassia fistula ${ }^{160}$ & Root & $\mathrm{CCl}_{4}$ & $\begin{array}{l}\text { SGOT, SGPT, ALP and } \\
\text { Total protein and histopathology }\end{array}$ \\
\hline Kyllinganemoralis ${ }^{161}$ & Rhizomes & $\mathrm{CCl}_{4}$ & ALT, AST, SALP, total bilirubin and histopathology \\
\hline Zanthoxylumarmatum DC ${ }^{162}$ & Bark & $\mathrm{CCl}_{4}$ & $\begin{array}{l}\text { ALT, AST, SALP, bilirubin total protein albumin, GSH and LPO, } \\
\text { Histopathology }\end{array}$ \\
\hline Trichosanthes cucumerina ${ }^{163}$ & $\begin{array}{l}\text { Whole } \\
\text { plant }\end{array}$ & $\mathrm{CCl}_{4}$ & $\begin{array}{l}\text { ALT, AST, SALP, bilirubin total protein albumin, GSH and LPO, } \\
\text { Histopathology }\end{array}$ \\
\hline $\begin{array}{l}\text { Cichorium } \\
\text { glandulosum }\end{array}$ & Root & $\mathrm{CCl}_{4}$ & AST, ALT, SALP, DPPH inhibition and LPO \\
\hline Carissa carandas Linn. ${ }^{165}$ & Root & $\mathrm{CCl}_{4}$ and APAP & $\begin{array}{l}\text { ALT, AST, SALP, bilirubin total protein Uric acid, GSH, LPO, SOD, } \\
\text { CAT and histopathology }\end{array}$ \\
\hline Cassia occidentalis ${ }^{166}$ & Leaf & APAP and Alcohol & $\begin{array}{l}\text { ALT, AST, SALP, bilirubin, albumin, serum cholesterol, serum total } \\
\text { lipids and histopathology }\end{array}$ \\
\hline Vitis minifera ${ }^{167}$ & Leaf & Alcohol & $\begin{array}{c}\text { AST, ALT, SALP, LDH, GGT, bilirubin, urea, creatinine, } \\
\text { histopathological studies }\end{array}$ \\
\hline $\begin{array}{l}\text { Azadirachta } \\
\text { indica }^{168}\end{array}$ & Leaf & Alcohol & AST, ALT, ALP, protein, albumin, GSH, SOD and CAT \\
\hline Emblica officinalis ${ }^{169}$ & Fruit & Alcohol & AST, ALT, LPO, SOD, CAT, GST, SALP and histology \\
\hline
\end{tabular}

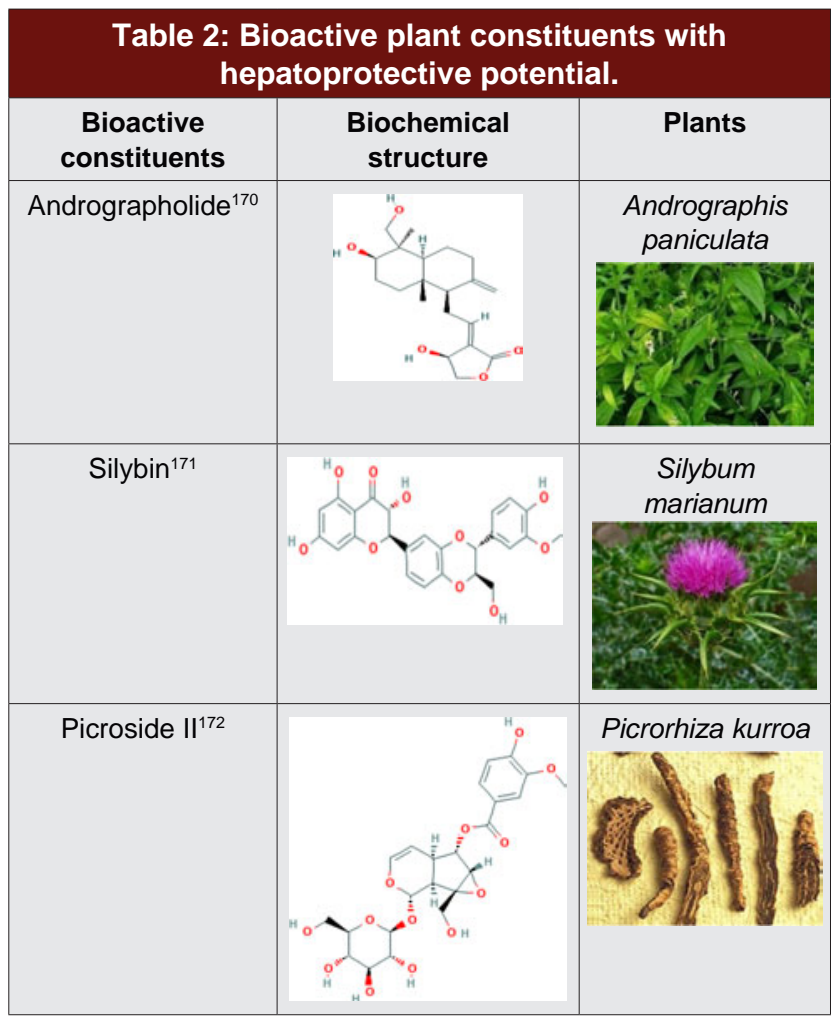

Continued...

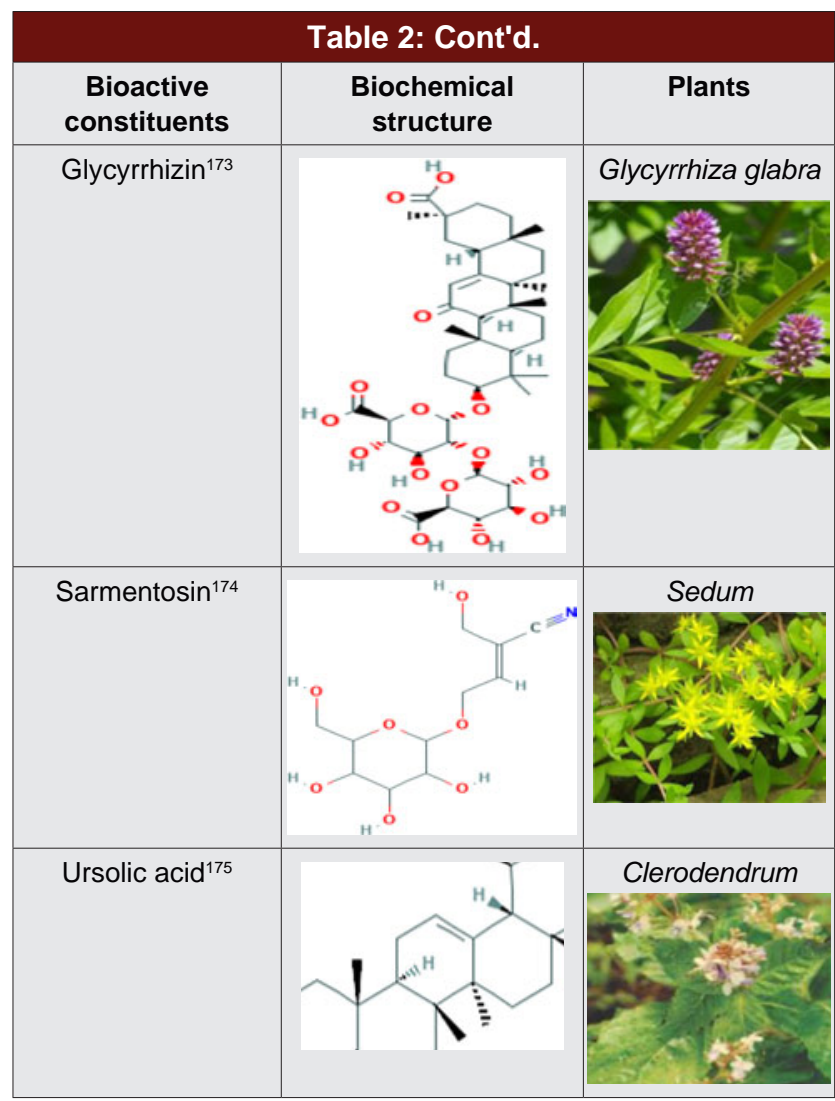

Continued... 


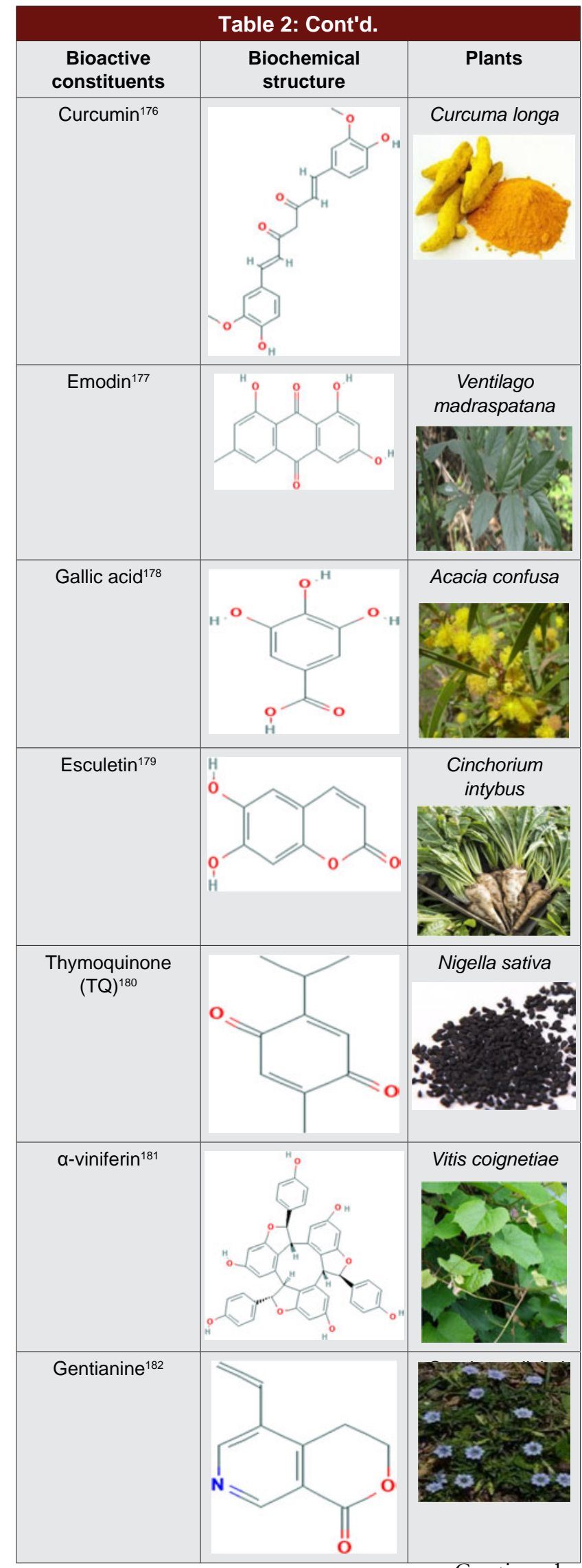

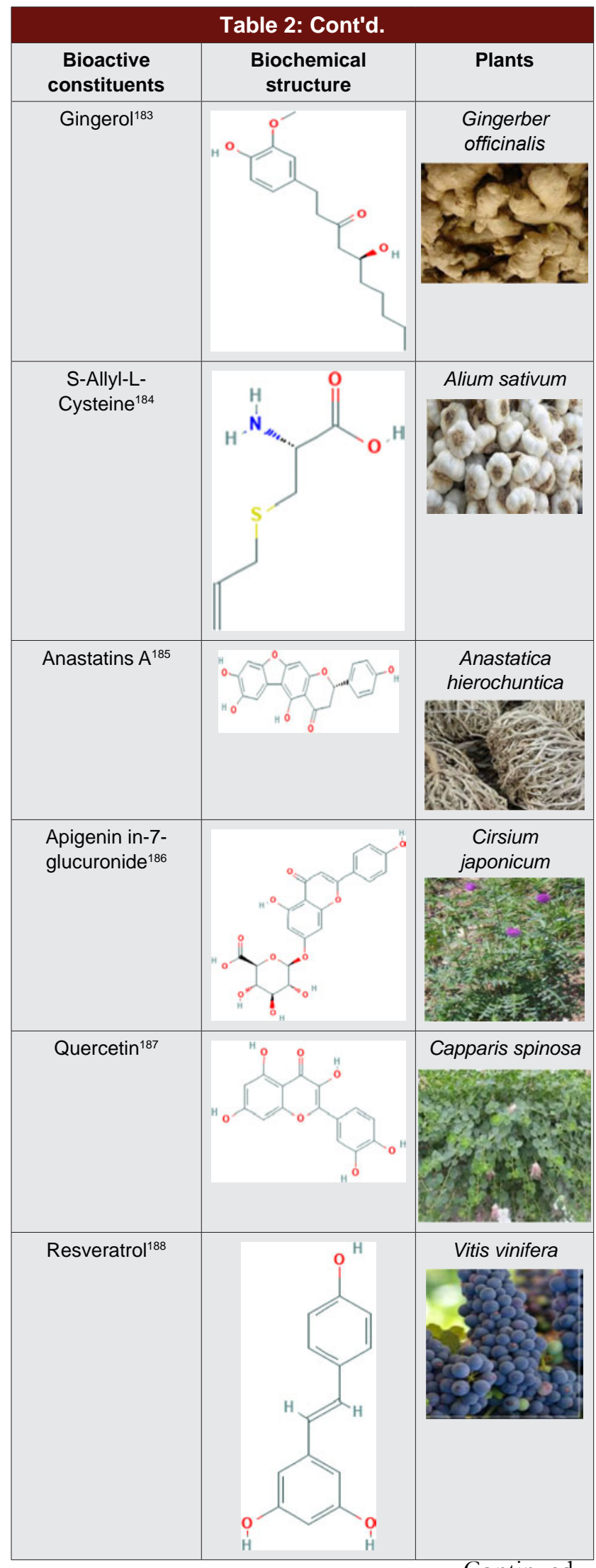

Continued...

Continued... 


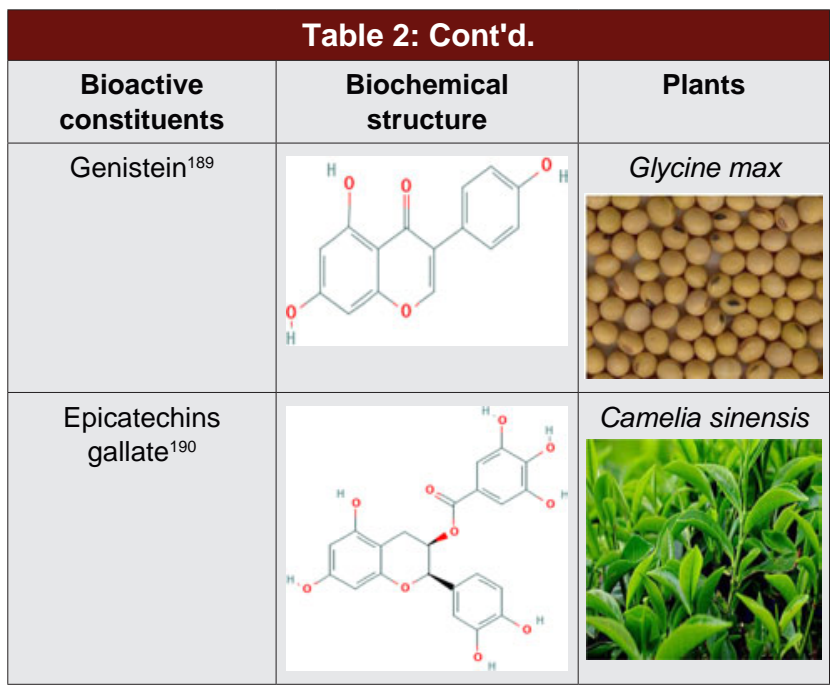

dose of APAP only when a dose $>125 \mathrm{mg} / \mathrm{kg}[7.5 \mathrm{~g}$ in a $60 \mathrm{~kg}$ individual] is absorbed and the likelihood of toxicity increased substantially as the absorbed dose exceeds $250 \mathrm{mg} / \mathrm{kg}$ and $\mathrm{LD}_{50}$ of APAP $3.7 \mathrm{~g} / \mathrm{kg}$ in male rats. ${ }^{24,25}$

Several investigators suggested that APAP toxicity was associated with increased level of hepatocellular enzymes vir., AST, ALT, LDH and SALP into circulation. ${ }^{26} \mathrm{It}$ is well documented that the antioxidant enzymes (SOD, CAT, GPx, GR, G-6-PDH and GST) were decreased by APAP induced liver toxicity. ${ }^{27,28}$ Marked increased in serum globulin, bilirubin and total protein with significant decreased the albumin level after paracetamol administration were seen. ${ }^{29}$ Some studies have implicated a role for mitochondrial damage in the toxic process initiated by APAP in hepatocytes. ${ }^{30}$ Inhibition of cellular respiration due to impairment of mitochondrial function, DNA damage, decreased activity of $\mathrm{Na}^{+}-\mathrm{K}^{+}$- ATPase were found in hepatocytes after paracetamol exposer. ${ }^{31,32}$ In vivo studies showed that APAP exposure induces DNA single-strand breaks in mice and rats, aneuploidy in rat embryo cells. ${ }^{33}$

\section{Carbon tetrachloride $\left(\mathrm{CCl}_{4}\right)$}

Carbon tetrachloride $\left(\mathrm{CCl}_{4}\right)$ is a chlorinated organic solvent and its overexposure maytoxic to many organs. It is a colorless and highly volatile liquid with a sweetish [ethereal] odor. Upon heating, it breakdowns to highly toxic fumes of phosgene. It is primarily utilized for production of chlorofluorocarbons that are used as refrigerants. It has also been served as an antihelminthic, insecticide dispersant, dry-cleaning agent, grain-fumigant and fire extinguisher. ${ }^{34}$ Carbon tetrachloride can be absorbed via oral (mouth) and inhalation (lungs) routes and dermal (skin) route both in humans and animals.
It is a well-known hepatic toxin used to induce liver damage in laboratory animals like mice and rat to evaluate hepatoprotective effect of medicinal plants. It is metabolized in the liver by an nicotinamide adenine dinucleotide phosphate [NADPH]-dependent CYP4502E1 enzyme, forming free radicals, trichloromethyl $\left({ }^{\circ} \mathrm{CCl}_{3}\right)$ radical and with further oxidation to trichloromethyl peroxy ('O-O- $\left.\mathrm{CCl}_{3}\right)^{3}{ }^{35,36}$ These free radicals attack on fatty acids in cell membranes and induce lipid peroxidation which cause further another reactive aldehydes (e.g., formaldehyde and acetaldehyde etc.). The aldehydes react with reduced glutathione [e.g., GSH], and reduces the GSH level in liver cells. GSH is an intracellular antioxidant which protects cells against free radical damage. ${ }^{37}$ Over production of free radicals by $\mathrm{CCl}_{4}$ metabolism may also induce DNA damage which contribute to the genotoxicity of $\mathrm{CCl}_{4}$. Lipid peroxidation also causes cell membrane disruption thereby hepatic enzymes such as Aspartate transaminase [AST] and alanine transaminase [ALT] and bilirubin content released into the blood stream. ${ }^{38}$ This in turn activates protein degradation inflammation and cell necrosis which can also contribute to cytotoxicity (Figure 3). ${ }^{39}$

$\mathrm{CCl}_{4}$ metabolites cause alteration in $\mathrm{Ca}^{2+}$ sequestration, lipid homeostasis and cytokines release and loss of energy metabolism. ${ }^{40}$ The metabolism of $\mathrm{CCl}_{4}$ has been investigated in the rat, rabbit, dog and human. ${ }^{41}$ Many investigators have utilized $\mathrm{CCl}_{4}$ to induce liver cirrhosis in experimental animals. ${ }^{42-44}$ Administration of $\mathrm{CCl}_{4}$ caused liver damage that mimics natural causes. It medicates changes in liver functions that ultimately lead to destruction of hepatocellular membrane. Peroxidation of lipids, covalent binding to macromolecules, disruption of metabolic mechanism in

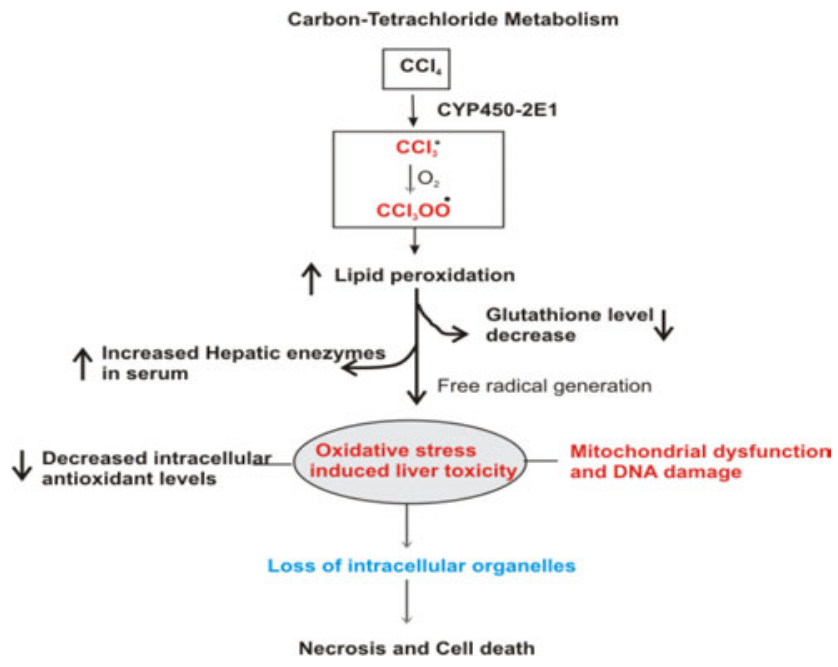

Figure 3: Metabolism of $\mathrm{CCl}_{4}$ with the hepatotoxicity. 
mitochondria, decrease levels of phospholipids, increase triglyceride levels, inhibition of calcium pump of microsomes and decreased activities of antioxidant enzymes Superoxide dismutase (SOD), Catalase, Glutathione peroxidase (GPx), Glutathione Reductase (GR) which may cause liver necrosis. ${ }^{45-47}$

The acute oral toxicity of $\mathrm{CCl}_{4}$ is relatively low with a median lethal dosage $\mathrm{LD}_{50}-13,000 \mathrm{mg} / \mathrm{kg}$ for mice. ${ }^{48}$ It is reported that liver is not only the target organ of $\mathrm{CCl}_{4}$ but also causes toxicity in other tissues such as kidneys, heart, lung, testis, brain and blood. ${ }^{49}$ An in vitro study indicated that the trichloromethyl radical also interacts with all four DNA nitogenous bases and bound preferentially to guanine and adenine and produces agenotoxic response in liver. ${ }^{50}$

$\mathrm{CCl}_{4}$ intoxication causes significant reduction in the level of microsomal enzymes, aniline hydroxylase and p-aminopyrine-N-demethylase, glucose-6-phosphatase activity and protein synthesis. ${ }^{51}$ It also activates Kupffer cells that cause death of the hepatocytes. ${ }^{52,53}$ Histopahological studied reported that $\mathrm{CCl}_{4}$ treated animals showed hydropic changes in centrilobular hepatocytes with single cell necrosis surrounded by neutrophils..$^{54,55}$ Congestion of central vein and sinusoids were seen with acute and chronic inflammatory cells infiltrating sinusoids mainly in the central zone. The midzonal and periportal hepatocytes showed mild to moderate degree of fatty change. The most prominent of which are destruction of the smooth and rough endoplasmic reticulum and reduction of Golgi complexes and mitochondria, inhibition of protein synthesis ${ }^{56}$ and its associated enzyme activities impaired secretion of triglycerides with resultant fat accumulation in liver. ${ }^{57}$ The $3 \mathrm{~mL} / \mathrm{kg}$, i.p. dose of $\mathrm{CCl}_{4}$ for $24 \mathrm{hr}$ showed fatty changes and infiltration of lymphocytes around the central veins and loss of cellular boundaries. ${ }^{58,59}$

\section{Alcohol (Ethanol)}

Alcohol addiction is a major public health burden and estimated to cause about $20-30 \%$ of liver cirrhosis. It also increased motor vehicle accidents worldwide. It is estimated that 15 to $30 \%$ of chronic heavy drinkers eventually develop severe liver diseases. Alcoholic fatty liver may progress to alcoholic hepatitis and finally to cirrhosis and liver failure. ${ }^{60}$ In the India, chronic alcohol abuse is the leading cause of liver cirrhosis. Alcohol, the most commonly consumed xenobiotic, generates ROS species whether it is used over a long period of time. ALD ranges from reversible fatty liver (steatosis), to more severe alcoholic hepatitis and fibrosis and cirrhosis and end stage liver disease. Also obesity with prolonged alcohol intake increase the risk of irreversible liver damage. ${ }^{61}$ People who consume or addicted alcoholic have the major risk to develop alcoholic liver disease (ALD) such as hepatitis and cirrhosis. ${ }^{62,63}$ ALD pathway includes elevation of $\mathrm{NADH} / \mathrm{NAD}+$ ratio, causing lipid accumulation and up-regulation of cytochrome P4502E1 (CYP2E1), resulting in oxidative stress and cellular inflammatory. ${ }^{64}$ Habitual consumption of Alcohol is one of the most common causes of liver disease in the world. ${ }^{65}$ There is increasing evidence that the prenatal environment can influence the risk of developing some chronic diseases in the offspring's later in life. ${ }^{66,67}$ Alcohol-related disorders are one of the challenging current health problems with far reaching medical, social and economic consequences. Long-term alcohol use potentially results in serious illnesses, including fatty liver, diabetes, hyper triglyceridaemia, cirrhosis and cardiovascular disease and dementia. ${ }^{6}$

In the hepatocyte, there are three systems that metabolizes ethanol located in three different cellular compartments: alcohol dehydrogenase located in the cytosol, the microsomal ethanol oxidizing system situated in the ER and catalase located in the peroxisomes. ${ }^{69}$ Alcohol is mainly metabolised in the liver. Normally about $10 \mathrm{gm}$ of ethanol is metabolised in one hour. Phase I metabolism is involved in the induction of alcohol metabolism enzymes, especially in the gastrointestinal tract where it is converted to the acetaldehyde. Acetaldehyde is known to produce toxic effects on the liver cells and retard the rate of phase II metabolism. Accumulation of acetaldehyde leads to the formation of protein adducts, resulting in metabolic disturbances (Figure 4). ${ }^{70}$

Recent studies have shown that cytochrome P-450 2E1 induced by ethanol has a high oxidase activity and plays

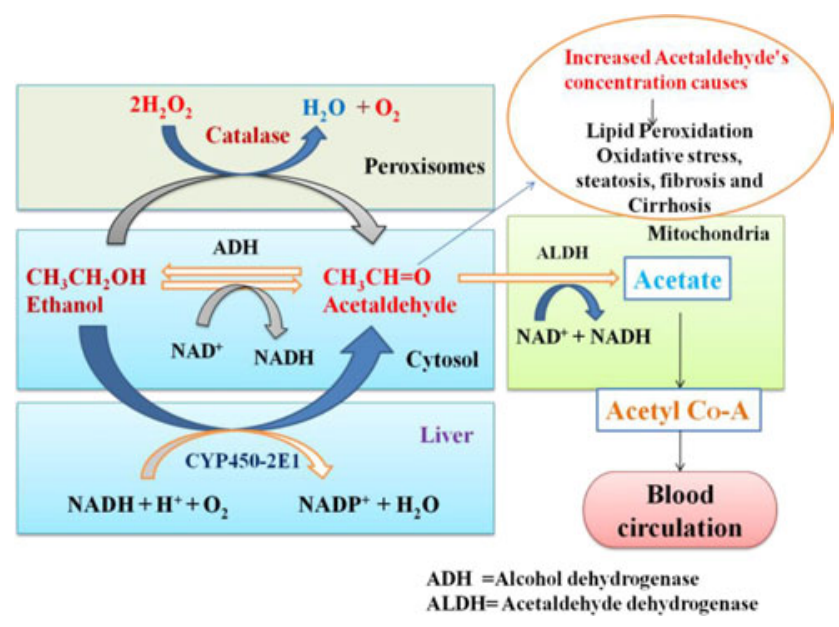

Figure 4: Oxidative pathway of Alcohol Metabolism with the hepatotoxicity. 
a crucial role in the microsomal generation of ROS that initiates membranous lipid peroxidation (LPO). ${ }^{71-73}$ This causes an imbalance between pro-oxidants and antioxidants. Enhanced oxidative stress in the liver due to chronic alcohol ingestion may be impaired antioxidant defense systems of the liver tissue. ${ }^{74,75}$ Free radicals or ROS such as hydroxy ethyl radical, superoxide and hydroxy radicals, which formed in ethanol mediated process, are responsible for alcohol induced oxidative stress and fatty liver. ${ }^{76}$

Several studies have reported that daily consumption of alcohol intake is associated with changes in plasma lipid concentrations, increased cholesterol and triglycerides in serum. ${ }^{77}$ It is reported that chronic alcohol intake leads to many cellular and tissue abnormalities such as alteration in liver enzymes (ALT, AST and SALP) which indicated the increased membrane permeability and necrosis in hepatocytes. ${ }^{78}$

Kupffer cells have a direct regulatory role in hepatocyte injury caused by ethanol by expressing tumor necrosis factor-alpha (TNF- $\alpha$ ). Ethanol ingestion may interrupt the pro-regenerative signal transduction that is initiated by injury-related cytokines such as TNF- $\alpha$ and interleukin-6 (IL-6) suggesting that TNF- $\alpha$ may have a critical role in pathogenesis of liver injury associated with alcoholic hepatitis. The biological actions of TNF- $\alpha$ include fever, neutrophilia and hypotension, clinical features that are also seen in patients with acute alcoholic hepatitis. ${ }^{79}$ Chronic alcohol abuse provokes successive hepatic changes, consisting of alcoholic steatosis, fibrosis, hepatitis and cirrhosis. Ethanol exposure for 4 weeks showed obvious damaging effect on liver tissue in the form of dilatation with congestion of the portal vein, with thickening of its wall and marked fibrosis in the portal area. ${ }^{80}$

\section{Non-Alcoholic fatty liver disease}

It is modern liver disease usually seen in obese or overweight people and children. Non-alcoholic fatty liver disease (NAFLD) refers wide a range of clinical conditions due to over accumulation of fat in the liver. ${ }^{81}$ In India, obesity is rising health problem particularly in urban areas which is more public health concerns including malnutrition. Overweight or obesity is reported about $30-65 \%$ of urban population of India. High-Fat Diet (HFD), unhealthy foods, physical inactivity and genetic factors. HFD is thought to be one of the main key factors for development of obesity. HFD is also main causative agent for nonalcoholic fatty liver diseases (NAFLD) leading to significant burden of morbidity and mortality in world population. ${ }^{82}$
Some diabetic patients may have insulin resistance due to obesity. In India, the rate of hepatic diseases including fatty liver in obese people has been reported to be much higher about $8-30 \% .{ }^{83}$ It is a chronic liver disease that affects a high proportion of the world's population and represents a major cause of liver-related morbidity and mortality. Fatty liver is characterized by accumulation of fats (Triglycerides) in the liver resulting in oxidative stress, steatosis, fibrosis and cirrhosis. ${ }^{84,85}$

\section{Antituberculosis drugs}

Tuberculosis (TB) is a serious infectious disease which can be fatal if not treated in time. TB is completely curable with regular and on time treatment with anti-Tuberculosis drugs like Isoniazid (INH), Rifampicin (RMP) and pyrazinamide (PZA) ${ }^{86}$ However, these anti-TB drugs are associated with drug-Induced Liver Injuries (DILI) and thus have their own drawbacks and ill effects on health system. N-acetyl transferase metabolize Isoniazid (INZ) to acetyl-isoniazid which in turn form acetyl hydrazine and reactive acetyl species. Rifampicin (RMP) increases the rate of reactive acetyl species formation. These reactive acetyl species cause oxidative stress leading to hepatotoxicity. ${ }^{87}$ Liver enzyme elevation is an indicator of Anti-TB DILI which ranges from 5-30\%. Extreme effects of Anti-TB treatment are liver injury, neurological disfunctioning and gastrointestinal ailment etc. ${ }^{88}$

\section{Medicinal Plants with Significant Hepatoprotective Activity}

\section{Andrographis paniculata (Family: Acanthaceae)}

Andrographolide, the active constituent isolated from the Andrographis paniculata's leaf and aerial part, which showed a significant hepatoprotectiv activity against APAP induced toxicity on ex-vivo preparation of isolated rat hepatocytes. ${ }^{89}$ Today, it is involved in about 26 different Ayurvedic formulations used to treat liver disorders such as jaundice and hepatitis. Andrographolide was reported to improve gall bladder function, increases bile flow and has been found to be as effective as silymarin in protecting the liver. It also has showed anti-diabetic effect in streptozocin-induced hyperglycaemic rats and diabetic nephropathy. It maintains the liver function enzymes (AST, ALT and LDH) by reducing the lipid peroxidation as well as regulate the level of glutathione and antioxidant enzymes (Superoxide dismutase, Catalase, Glutathion peroxidase and Glutathione reductase) in carbon tetrachloride induced toxicity. ${ }^{90}$ 


\section{Boerhaavia diffusa (Family: Nyctaginaceae)}

It is known as Punarnava. The roots of Boerhavia diffusa are known tradionally for liver cure and used for the treatment of various liver problems due to their safety and efficacy. The root contain various types of flavonoids, isoflavonoids, glycoproteins and steroids which make it potent free radical scavenger. ${ }^{91}$ The root extract hasb been reported to have potent antiviral efficacy of against hepatitis B and C viruses. ${ }^{92}$ Its extract also increases normal bile flow and antioxidant defence system with improving cellular morphology in heptotoxicity in rats suggesting its strong hepatoprotective activity. ${ }^{93}$

\section{Eclipta alba (Family: Asteraceae)}

In ayurvedic medicine, its leaf extract is considered a powerful liver tonic and rejuvenative. It also has traditional external uses, like athlete foot, eczema and dermatitis. The alcoholic extract of Eclipta alba exhibited antihepatotoxic effect in carbon tetrachloride and galactosamine induced acute liver damage. It showed significantly stimulatory effect on hepatocyte cell regenration. regulates the levels of hepatic serum enzymes (AST and ALT) hepatic microsomal drug metabolizing enzymes and restores the normal architecture of liver cells against toxicity. ${ }^{94}$ It has been reported that phytochemiclas wedelolactone and demethylwedelolactone may possible components behind the hepatoprotective effect against liver disorders. ${ }^{95}$

\section{Picrorhiza kurroa (Family: Scrophulariaceae)}

Current research studies reported that Picrorbiza kurroa has many pharmacological property such as hepatoprotective, anticholestatic, antioxidant and immune-modulating activity. It is reported that picroside-I and kutkoside, obtained from the ethanolic extract of the roots and rhizome of Picrorbiza kurroa, are good scavengers of free radiclas [superoxide anion $\mathrm{O}^{2} \bullet$ ] and inhibited Lipid peroxidation in liver tissue. ${ }^{96}$ Ethanolic extract of this plant showed restoration of bilirubin and activity of AST, ALT, ALP and LDH against acetaminophen (APAP) induced liver toxicity. Its extract treated with APAP in experimental animals also showed protection on hepatic cells thereby confirming its hepatoprotective activity. ${ }^{97}$ Its principal ingredient was used $(50 \%)$ involved in a herbal formulation, known as Arogya-wardhani. A research study also reported its hepatoprotective efficacy against viral hepatitis and alcohol induced liver damage. ${ }^{88,99}$

\section{Tephrosia purpurea (Family: Fabaceae)}

Tephrosia purpurea is locally known as Sarapunkha and used for diabetes mellitus in Ayurvedic medicine. It is considered to be beneficial for liver, spleen and kidney disorders. ${ }^{100}$ Experimental studies have demonstrated its antiulcer and hepatoprotective effects. ${ }^{101}$ Rats treated with Tephrosia purpurea at $500 \mathrm{mg} / \mathrm{kg}$ in thioacetamide induced toxicity resulted in a significant reduction in serum liver enzymes: AST, ALT and alkaline phosphatase and total bilirubin and significant improvement was seen in the levels of liver glutathione and MDA content (a Lipid peroxidation product) and antioxidant enzymes (SOD and Calase). Histological examination confirmed the protection of liver by plant extract against toxicity. ${ }^{102}$ It was also found effective in cirrhosis and viral hepatitis in clinical trials. ${ }^{103}$

\section{Phyllanthus amarus (Family: Phyllanthaceae)}

Phyllanthus amarus (PA) has been reported to possess hepatoprotective, antidiabetic, antihypertensive, analgesic, anti-inflammatory, antidiarrheal and antimicrobial properties. ${ }^{104,105}$ Its antiviral activity against hepatitis B virus has been well established. ${ }^{106}$ In vivo studies demonstrated that the treatment of PA extract at $75 \mathrm{mg} / \mathrm{kg}$ p.o. for 7 days with ethanol exposure for 21 days restored the normal liver function by restoring the levels of AST, ALT and TNF- $\alpha$ towards toward control group. In vitro study demonstrated the hepatoprotective effects of aqueous extract of Phyllanthus amarus in ethanol-induced rat hepatic injury. MTT assay (2,5 diphenyl tetrazolium bromide) showed the good cell viability and protection of hepatocytes cell lines in alcohol treated rat primary cultured hepatocytes. Histopathological study also revealed the beneficial effect of PA with its potential antioxidant property. ${ }^{107}$

\section{Mimosa pudica (Family: Mimosaceae)}

Mimosa pudica known as Chue Mue in Hindi, is a stout stragling prostrate shrubby plant. Leaves and stem of the plant have been reported to contain an alkaloid mimosine, leaves also contain mucilage and root contains tannins. The oral administration of the Mimosa pudica for 10 days in rat animals protected the levels of hepatic parameters such as total bilirubin, alkaline phosphatase (ALP), acid phosphatase (ACP), lipid peroxide (LPO) in tissue and serum, gamma glutamyl transferase $(\gamma-G T)$, aspartate transaminase (AST) and alanine transaminase (ALT) against sub-acute toxicity induced by $\mathrm{CCl}_{4}$ exposure. ${ }^{108}$ Mimosa pudica is used for its anti-hyperglycemic, antidiarrhoeal, fever, piles, jaundice, leprosy, ulcers and small pox. ${ }^{109}$ Histopathological studies revealed that the $M$. pudica extract exhibited protection of the liver tissue with the improvement in cellular morphology as compared to $\mathrm{CCl}_{4}$ treated group. ${ }^{110}$ 


\section{Hygrophila spinosa (Family: Acathaceae)}

Its common name is Nirmulli or Gokulakanta. The plant has low molluscicidal activity against Bulinus truncates and antitumor activity. ${ }^{111}$ Traditionally, the aerial parts and the roots are Hygrophila spinosa used as demulcent, aphrodisiac, diuretic, urinary and liver tonic, the root contains an alkaloid named hygrosterol rich in antioxidants. The pharmacological properties such as hepatoprotective, antibacterial, antitumor and antidiabetic of Hygrophila spinosa were investigated by various researchers. Carbon tetrachloride induced liver damage was protected by 15 days treatment of the aqueous extract of the plant root indicating its hepatoprotective activity. The increased level of serum marker enzymes Aspartate transaminase, Alanine transaminase and Gama Glutamyl in $\mathrm{CCl}_{4}$ treated rats were found to be restored nearly to normal value after therapy of the plant root extract. The histological observations also proved the hepatoprotective action of the root of Hygrophila spinosa. ${ }^{112}$

\section{Adhatoda vasica (Family: Acanthaceae)}

A. vasica, an evergreen gregarious and perennial shrub. It is antioxidant and chemopreventive agent. It enhances the activities of glutathione-S-transferase in the liver of mice. Extract of leaves is extensively used in cough, asthma, bronchitis, tuberculosis, inflammation, allergy and jaundice. ${ }^{113,114}$ The hepatoprotective activity of Ethyl acetate extract of Adhatoda vasica $(100 \mathrm{mg} / \mathrm{kg}$ and $200 \mathrm{mg} / \mathrm{kg})$ was also evaluated on $\mathrm{CCl}_{4}(1 \mathrm{ml} / \mathrm{kg} /$ bodyweight) induced liver damage in rat model. The statistically analysis of biochemical findings showed the significant lowered the increased the levels of serum Alanine aminotransferase, (ALT), Aspartate aminotransferase (AST), Alkaline Phosphatase (ALP) and also bilirubin when compared with $\mathrm{CCl}_{4}$ treated animals. Histopathological observations also coincided with the biochemical findings results, however $200 \mathrm{mg} / \mathrm{kg}$ dose was found to be more protective and suggested $A d h a t o d a$ vasica possess pronounced hepatoprotective effect against $\mathrm{CCl}_{4}$ induced liver damage. ${ }^{115}$ The treatment of aqueous extract of Adhatoda vasica leaf $(100 \mathrm{mg} / \mathrm{kg}$ and $200 \mathrm{mg} / \mathrm{kg}$, p.o. for six days) with hepatotoxicity induced by paracetamol $(2 \mathrm{gm} / \mathrm{kg})$ reduced the levels of serum ALT and AST same as positive control silymarin. ${ }^{116}$ Thus, the leaves of Adhatoda vasica have significant hepatoprotective activity.

\section{Capparis sepiaria (Family: Capparaceae)}

Capparis sepiaria is distributed in dry parts of India, in Deccan peninsula and Andamans. In Ayurveda, it is used in the treatment of tumors, prevents inflammation and also acts as blood purifier. Local people used the root of this plant to cure from snake bite and skin diseases. ${ }^{117}$ The hepatoprotective effect of the alcohol extract of Capparis sepiaria (CS) Linn. (Capparaceae) stem was assessed in carbon tetrachloride $\left(\mathrm{CCl}_{4}\right)$ induced toxicity in albino rats. The pretreatment with alcohol extract of C. sepiaria (100 mg/ $\mathrm{kg}$ for 7 days) and the positive control silymarin $(25 \mathrm{mg} / \mathrm{kg})$ orally for 7 days against $\mathrm{CCl}_{4}$ induced toxicity resulted in a significant protection of elevated levels of serum marker enzymes (AST and ALT) and bilirubin which is almost normal when compared with the effect of the positive control, silymarin. Histopathological observations was further confirmed the hepatoprotective effect of CS and proved the effect of CS in preventing hepatocellular necrosis and cellular degeneration caused bt $\mathrm{CCl}_{4}$ exposure. ${ }^{118}$ Thus CS extract may bring the almost normal histological architecture of the liver.

\section{Aerva lanata (Family: Amaranthaceae)}

Aerva lanata known as knot grass. It is an herbaceous perennial weed growing wild in the hot regions of India. It is claimed to be useful as diuretic, anthelmintic, antidiabetic, expectorant and hepatoprotective in traditional system of medicine. ${ }^{118}$ Antimicrobial, cytotoxicity and anti-inflammatory activity has been reported. ${ }^{119}$ It contains various flavanoid such as kaempferol, quercetin, isohamnetin, galactoside, flavanone glucoside pernisol, persinoside A and B. The hydro alcoholic exract of this plant has shown Hepatoprotective activity against carbon tetra chloride induced liver damage. The hepatoprotective activity of petroleum ether and methanolic extracts of the roots, stem bark and leaves root were studied in carbon tetrachloride induced hepatotoxicity in albino rats. The extracts at a dose of 200 and $300 \mathrm{mg} / \mathrm{kg}$ minimised the histopathological changes and reduced the raised hepatic serum marker enzymes (AST, ALT and serum alakaline phosphatase, SALP) and also decreased the levels of bilirubin and tissue lipid peroxidation. The plant extract also increased the activities of antioxidant enzymes (catalase, superoxide dismutase, glutathione-S-transferase, glutathione peroxidise, glutathione reductase) in $\mathrm{CCl}_{4}$ treated animals. ${ }^{120}$

\section{Solanum nigrum (Family: Solanaceae)}

Solanum nigrum is known as black night shade, makoy, deadly nightshade. It is folklore medicine used for the treatment of various ailments related to gastric and liver problem. The identified major phytochemical compounds are glycoalkaloids (solamargine, solasonine and solanine), glycoproteins and polysaccharides gallic acid, catechin, protocatechuic acid, caffeic acid, 
epicatecin, rutin and naringenin). ${ }^{121} \mathrm{It}$ is mainly used in polyherbal formulations targeting liver diseases problems. Previous studies have been reported that S. nigrum extract provides hepatoprotection by mitigating $\mathrm{CCl}_{4}$ induced liver damage. ${ }^{122,123}$ The fruit extract of S. nigrum $(100,200,300 \mathrm{mg} / \mathrm{kg}$ dose body weight/day) was administered for 30 days along with $\mathrm{CCl}_{4}$ confirmed the antioxidant activity ad hepatoprotective role of $S$. nigrum by restoring the liver function enzymes and reducing the oxidative stress caused by $\mathrm{CCl}_{4}$ induced toxicity. ${ }^{124}$

Liver histopathology result demonstrated that Solanum nigrum extract mitigated the changes of liver lesions including hepatic cells cloudy swelling, hepatic necrosis and fibrous connective tissue proliferation induced by $\mathrm{CCl}_{4}$ intoxication in rats. ${ }^{125}$ The hepatoprotective effect of plant extract might be associated to its modulation on cytochrome P-450 enzymes system with improving the antioxidant and free radical scavenger effects.

\section{Wedelia chinensis (Family: Asteraceae)}

Wedelia chinensis is a perennial herb. Traditionally, it is used as anti-inflammatory, antithelmentic, including respiratory infections and pain. ${ }^{126}$ The ethanolic extract of Wedelia chinensis at doses of $250 \mathrm{mg} / \mathrm{kg}$ p.o and $500 \mathrm{mg} / \mathrm{kg}$ p.o. was evaluated for its hepatoprotection against carbon tetrachloride $\left(\mathrm{CCl}_{4}\right)$ induced hepatotoxicity in rat model. The $\mathrm{CCl}_{4}$ administration significantly increased levels of biochemical parameters like aspartate aminotransferase (AST), alanine aminotransferase (ALT), alkaline phosphate (ALP), total bilirubin and total protein along with histopathological changes which were protected by therapy of Wedelia chinensis. ${ }^{127-129}$ Hence, the results showed that Wedelia chinensis exhibits significant dose dependent hepatoprotective activity. The reducing cellular necrosis and fatty infiltration was seen in the histological findings indicating the recovery of hepatic cells.

\section{Morus alba (Family: Moraceae)}

It is known as white mulberry. All parts of this plant are useful to cure of cardiovascular disease, liver and spleen disorders. Recent research study has shown that this herb has free radical scavenging activity, hypolipidemic effect, antioxidant, antibacterial and anti-inflammatory properties. White mulberry leaf contains triterpenes, sterols, bioflavonoids, coumarins, alkaloids, amino acids and organic acids. ${ }^{130}$ Morus alba showed the presence of various phytochemical compounds such as alkaloids, flavonoides, glyosides, tannins and steroids. ${ }^{130}$ The hydroalcoholic extract at dose of $800 \mathrm{mg} / \mathrm{kg}$ of Morus alba L. leaves was studied for hepatoprotection against carbon tetrachloride induced hepatotoxicity. The hydroalcoholic extract of plant showed the significant liver protective effect by decreasing the hepatospecific serum marker enzymes: aspartate aminotransferase (AST) and alanine aminotransferase (ALT) and haxobarbitone induced sleep time. The treatment of Morus alba L. leaves resulted the less pronounced destruction of the liver, there was no fibrosis and inflammation were observed as compared with $\mathrm{CCl}_{4}$ treatment group in experimental animals. Leaf extract of Morus alba found to be more hepatoprtoective effect against carbon tetrachloride $\left(\mathrm{CCl}_{4}\right)$ induced hepatotoxicity. Its leaves extract is effectively prevented the $\mathrm{CCl}_{4}$ produced biochemical and histological changes in the liver by reversing the biochemical and oxidative parameters toward normal group. ${ }^{131}$

\section{Zingiber officinale (Family: Zingeberaceae)}

It is known as ginger. The rhizome of $Z$. officinale is commonly used in cooking. It is being used in homes for curing cough, cold, fever and liver problems. ${ }^{132}$ Gingerols and shogaols are the main active chemical constituents present in ginger exhibited strong antioxidant activity, anti-inflammatory, antipyretic, antihepatotoxic and cardioprotective properties. It has been reported to have antioxidant and hepatoprotective agent against $\mathrm{CCl}_{4}$ induced liver fibrosis. ${ }^{133}$ The elevated levels of $\mathrm{RBC}$ counts and hemoglobin concentration with alanine aminotransferase, aspartate aminotransferase, alkaline phosphatase and gamma glutamyltransferase activities and the serum triglycerides and cholesterol concentration were observed in the $\mathrm{CCl}_{4}$ treated animals as compared to control group. Methanol extract of ginger (250 and $500 \mathrm{mg} / \mathrm{kg}$ ) significantly restored the carbon tetrachloride-induced above parameters. The hepatoprotective effect of ginger was also proved by the histopathological examination of liver tissue in $\mathrm{CCl}_{4}$ treated rats. Ginger extract regulated the altered biochemical profile due to $\mathrm{CCl}_{4}$ intoxication towards normalization. ${ }^{134}$ Ginger maintained the integrity of plasma membrane and enchanced the liver regenerative capacity which might be due to its potent antioxidant activity against hepatotoxicity.

\section{Rosa damascena (Family: Rosaceae)}

Rosa damascena is an ornamental plant. It is generally used for the treatment of respiratory problem and headache and remedy for relaxing effects, anxiety and depression. ${ }^{135}$ It is one of the ingredient used in the preparation of beauty cosmetics. It has many therapeutic effects, including laxative, antispasmodic and 
cardiotonic. ${ }^{136}$ The major compounds such as kaempferol, quercetin, glycosides, arabinosides, rhamnosides were found in flower parts of Rosa damascena exhibited free radical scavenging activity. Hepatoprotective and antioxidant property of Rosa damascena Mill. have been reported against acetaminophen-Induced hepatotxicity in Albino Rats.

The flower extract of Rosa damascena Mill. Showed promising in vitro free radical scavenging potential. It neutralizes superoxide radical, hydroxyl radical and DPPH radical. Oral administration of Rosa damascena extract (50 mg/kg body weight) significantly reduced the levels of primary liver serum enzymes alkaline phosphatase (ALP), glutaminepyruvate transaminase (GPT) and glutamine oxaloacetate transaminase (GOT) activity along with tissue lipid peroxide level against $\mathrm{CCl}_{4}$ induced acute liver damage in rats. These above results were further confirmed by histological examination of liver section indicated that that R. damascena could protect from the $\mathrm{CCl}_{4}$ caused liver damage dues its free radical scavenging activity. ${ }^{137}$

\section{Rheum emodi (Family: Polygonaceae)}

Rheum emodi is known as revan chini. It locally called Indian Himalayan Rhubarb is traditionally used as a medicine. The roots of this plant has been reported to possess hepatoprotective, antidiabetic, antioxidant, antifungal, antimicrobial and nephroprotective activities. ${ }^{138,139}$ The major phytochemicals present in root part are emodin, tannin, gallic acid and lignan. The root part is used to treat kidney stones, gout and jaundice by the local people. Its hepatoprotective effects (aqueous and methanolic extracts) were studied against liver damage induced by paracetamol in albino rats. ${ }^{140}$

$\mathrm{CC}_{4}$ induced altered levels of hepatic serum markers i.e. ALT, AST, ALP, albumin and bilirubin were regulated by administration of Rheum emodi root extract. Rheum emodi extract also reversed the hitological changed caused by $\mathrm{CCl}_{4}$ intuced toxicity which might be due its antihepatotoxic effect.

\section{Nymphaea alba (Family: Nymphaeaceae)}

Nymphaea alba L. (N. alba), is known as the European water lily, White Lotus, or Nenuphar. Being as an aquatic flowering plant, $N$. alba was widely used traditionally as an antiseptic, an astringent, antioxidant and in insomnia. ${ }^{141}$ The N. alba flower is reported to have antioxidant, anti-inflammatory as well as hepatoprotective effect. ${ }^{142,143}$ There are many phyto-constituents such as ellagic and Gallic acid, quercetin, kaempferol, isokaempferide, apigenin and their glycosides have been identified in the flowers Nymphaea alba L. The hepatoprotective effect of $\mathrm{N}$. alba against $\mathrm{CCl}_{4}$-induced hepatotoxicity was studied and found good hepatoprotective agent. ${ }^{144}$ It has also been reported to have ameliorative effect against isoniazid induced hepatotoxicity in rats. ${ }^{145}$ The significant reduction in biochemical parameters (SGOT, SGPT, ALP, Bilirubin) and cholesterol level as compared to control group was seen after administration of ethanolic extract (200 and $400 \mathrm{mg} / \mathrm{kg}$ ) of Nymphaea alba. Maximum inhibition was obtained at dose $400 \mathrm{mg} / \mathrm{kg}$ of Ethanolic Extract of Nymphaea alba in both model. The extract also prevented necrosis of the liver and promoted, to some extent liver generation.

\section{Cichorium intybus (Family: Asteraceae)}

It is knows as Chicory. Cichorium intybus is a powerful hepatic stimulant that increases bile-secretion, promotes digestion. Experimental evidence has proved its action on liver glycogen. ${ }^{146,147}$ Cichorium intybus reported to have significant antihepatotoxic effect on $\mathrm{CCl}_{4}$ induced biochemical and histological changes. ${ }^{148}$ The aqueousmethanol seed extract of $C$. intybus has shown antioxidant and hepatoprotective effect on markers of liver function in the serum (AST and ALT), lipid peroxidation, antioxidant enzyme (SOD) levels and hepatic histopathology of the liver in rats with $\mathrm{CCl}_{4}$-induced hepatotoxicity against hepatotoxicants. ${ }^{149}$

It is folklore medicine used as an antimalarial medicine. The sesquiterpene lactones lactucin and lactucopicrin have been identified in root of Chicory as an antimalerial drug. ${ }^{150}$ The flowers of the chicory plant are used as a tonic and appetite stimulant and for the treatment of gallstones, gastroenteritis, sinus problems, cuts and bruises. Jigrine is one of the main ingredients of Chicory seeds, a commercial product of India used for the treatment of various diseases of the liver. ${ }^{151}$

\section{Silybum marianum (Family: Asteraceae)}

A well-known Hepatoprotective plant and it is a flavonolignan derived from the seeds of Silybum marianum called as milk thistle. It has good hepatoprotection in various hepatotoxic models of experimental liver disease in laboratory animals. ${ }^{152}$ It has been clinical tested hepatoprotective drug and used for the alcoholic fatty liver, jaundice, viral hepatitis and drug-induced liver diseases. Hepatoprotective activity of silymarin has been reported in acute and chronic liver disease by various researchers across the world against carbon tetrachloride, alcohol, paracetamol, galactosamine and thioacetamide toxicity. ${ }^{153}$ Scientific and clinical studies on Silibinin confirmed that it has in vivo, in vitro and in silico potential hepatoprotective, anti-inflammatory 
and immune-modulating effects. It has anti-inhibitory effect on hepatitis $\mathrm{C}$ virus (HCV), NS5B polymerase and antioxidative stress, antifibrosis and anticancer activities. ${ }^{154}$ Animal studies suggested that silymarin flavoliganans increases hepatic glutathione and antioxidant enzymes levels generation in hepatocytes. It helps in drug detoxification and also acts positive modulatior for liver regeneration against liver diseases. Silybin blocks the regulatory molecules such as CDK2, CDK4, cyclin E and cyclin D1 proteins in the cell division of cancer cells. ${ }^{155}$

Silymarin is standard drug used to compare the hepatoprotective activity of the other plant extract. Its mechanism of action includes inhibition of hepatotoxin binding to receptor sites on the hepatocyte membrane, reduction of glutathione oxidation to enhance its level in the liver and intestine, antioxidant activity and stimulation of ribosomal RNA polymerase and subsequent protein synthesis leading to enhanced hepatocyte regeneration. Silymarin may make a breakthrough as a new approach to protect other organs in addition to liver. The most remarkable use of silymarin is in the treatment of mushroom poisoning, hepatitis, alcoholic liver disease and cirrhosis, psoriasis and hypercholesterolemia. ${ }^{156}$

\section{CONCLUSION}

This study compiled the various pharmacological properties of medicinal plants which have been studied experimentally. However, there is urgent to identify and characterize the lead compound derived from the plants which can be potential candidates for hepatoprotection. The hepatoprotective action of medicinal plants may be related to its mitigation of oxidative stress and well as modulation of metabolic pathways involved in hepatotoxicity. Phytochemicals rich medicinal plants are source of good antioxidant activity which play an important role to combat against hepatic injury. These data may provide a rational for further studies on pharmacological evaluation of hepatoprotective medicinal plants in systematic manner.

\section{ACKNOWLEDGEMENT}

The author expresses deep thanks to Indira Gandhi National Open University, Maidan Garhi, New Delhi -110068 (INDIA).

\section{CONFLICT OF INTEREST}

The author declares no conflict of interest.

\section{ABBREVIATIONS}

WHO: World Health Organisation; APAP: Acetaminophen; NAPQI: N-Acetyl-p-benzo-Quinone; $\mathbf{C C l}_{4}$ : Carbon Tetrachloride; ${ }^{-} \mathbf{C C l}_{3}$ : Trichloromethyl radical; AST: Aspartate transaminase; ALT: Alanin transaminase; SALP: Serum Alkaline transaminase; SOD: Superoxide dismutase; GR: Glutathione Reductase; GPx: Glutathione peroxidase; CAT: Catalase; $\mathbf{L D}_{50}$ : Lethal dose; ALD: Alcoholic liver disease; CYP2E1: Cytochrome P450-2E1; ROS: Reactive oxygen species; LPO: Lipid peroxidation; TNF- $\alpha$ : Tumor necrosis factor- $\alpha$; IL-6: Interleukin-6; NAFLD: Non alcholic Fatty liver diseases; HFD: High Fat Diet; TB: Tuberculosis; INH: Isoniazid; RMP: Rifampicin; PZA: Pyrazinamide.

\section{REFERENCES}

1. Su LJ, Ding GW, Yang ZL, Zhang SB, Yang YX, Xu CS. Expression patternsand action analysis of genes associated with hepatitis virus infection during rat liver regeneration. World J Gastroenterol. 2006;12(47):7626-34.

2. Lu Y, Hu D, Ma S, Zhao X, Wang S, Wei G, et al. Protective effect of wedelolactone against $\mathrm{CCl}_{4}$-induced acute liver injury in mice. Int Immunopharmacol. 2016;34:44-52.

3. Woolbright $B L$, Jaeschke $H$. The impact of sterile inflammation inacute liver injury. J Clin TransI Res. 2017;3(1):170-88.

4. Masuda Y. Learning toxicology from carbon tetrachloride-induced hepatotoxicity. J Pharm Soc Jpn. 2006;126(10):885-99.

5. Singh D, Cho WC, Upadhyay G. Drug-Induced Liver Toxicity and Prevention by Herbal Antioxidants: An Overview. Fron Physiol. 2016;6:363.

6. Adewale OB, Adekeye AO, Akintayo CO, Onikanni A, Saheed S. Carbon tetrachloride $\left(\mathrm{CCl}_{4}\right)$-induced hepatic damage in experimental Sprague Dawley rats: Antioxidant potential of Xylopia aethiopica. Int J Pharmacol. 2014;3(2):118-23.

7. Zuzana P, Marie H, Helena D, Eva S, Alena L, Lenka B, et al. Silymarin prevents acetaminophen-induced hepatotoxicity in mice. PLoS One. 2018;13(1):e0191353.

8. Wang $X$, Wu Q, Liu A, Anadón A, Rodríguez J. Martínez-Larrañaga M, et al. Paracetamol: Overdose-induced oxidative stress toxicity, metabolism and protective effects of various compounds in vivo and in vitro. Drug Metab Rev. 2017;49(4):395-437.

9. Yang J, Li Y, Wang F, Wu C. Hepatoprotective effects of apple polyphenols on $\mathrm{CCl}_{4}$-induced acute liver damage in mice. J Agric Food Chem. 2010;58(10):6525-31.

10. Fallah $\mathrm{HH}$, Alavian SM, Heshmat R, Heydari MR, Abolmaali K. The efficacy of Liv- 52 on liver cirrhotic patients: A randomized, double-blind, placebocontrolled first approach. Phytomedicine. 2005;12(9):619-24.

11. Murugaian P, Ramamurthy $\mathrm{V}$, Karmegam N. Hepatoprotective Activity of Wedelia calendulacea L. against Acute Hepatotoxicity in Rats. Res J Agri Biol Sci. 2008;4(6):685-7.

12. Shakya AK. Medicinal plants: Future source of new drugs. I Journal of Herbal Med. 2016;4(4):59-64.

13. Jain S, Mohan R, Rai R. Ocimum sanctum as an Herbal Medicine: A Review. Int J Oral Maxillofac Implants. 2015;1:1-12.

14. Jose JK, Kuttan R. Hepatoprotective activity of Emblica officinalis and Chyavanaprash. J Ethnopharmacol. 2000;72(1-2):135-40.

15. Bunchorntavakul C, Reddy KR. Acetaminophen-related hepatotoxicity. Clin Liver Dis. 2013;17(4):587-607.

16. Michaut A, Moreau C, Robin MA, Fromenty B. Acetaminophen-induced liver injury in obesity and nonalcoholic fatty liver disease. Liver Int. 2014;34(7):e171-9. 
17. Schilling A, Corey R, Leonard M, Eghtesad B. Acetaminophen: Old drug, new warnings. Cleve Clin J Med. 2010;77(1):19-27.

18. Grattagliano I, Leonilde B, Catia VD, Wang HH, Wang DQH, Portincasa P. Biochemical mechanisms in drug-induced liver injury: Certainties and doubts. World J Gastroenterol. 2009;15(39):4865-76.

19. Jaeschke $H$, McGill MR, Williams CD, Ramachandran A. Current issues with acetaminophen hepatotoxicity-a clinically relevant model to test the efficacy of natural products. Life Sci. 2011;88(17-18):737-45.

20. Tirmenstein MA, Nelson SD. Subcellular binding and effects on calcium homeostasis produced by acetaminophen and a nonhepatotoxicregioisomer, 30-hydroxyacetanilide, in mouse-liver. J Biol Chem. 1989;264(17):9814-9.

21. Bjprnssam E, Olsson R. Suspected drug-induced liver fatalities reported to the WHO database. Digest Liver Dis. 2006;38(1):33-8.

22. Isik B, Bayrak R, Akcay A, Sogut S. Erdosteine against acetaminophen induced renal toxicity. Mol Cell Biochem. 2006;287(1-2):185-91.

23. Jaeschke H, Xie Y, McGril MR. Acetaminophen-induced Liver Injury: From Animal Models to humans. J Clin Transl Hepatol. 2014;2(3):153-61.

24. Yoon E, Babar A, Choudhary M, Kutner M, Pyrsopoulos N. AcetaminophenInduced Hepatotoxicity: A Comprehensive Update. J Clin Transl Hepatol. 2016;4(2):131-42.

25. Nirala SK, Bhadauria M. Propolis Reverses Acetaminophen Induced Acute Hepatorenal Alterations: A Biochemical and Histopathological Approach. Arch Pharm Res. 2008;31(4):451-61.

26. Kuvandik G, Mehmet D, Ahmet N, Zafer Y, Rami H, Ahmet K, et al. Effects of Erdosteine on Acetaminophen-induced Hepatotoxicity in Rats. Toxicol Pathol. 2008;36(5):714-9.

27. Manokaran S, Jaswanth A, Sengottuvelu S, Nandhakumar J, Duraisamy R, Karthikeyan D, et al. Hepatoprotective Activity of Aerva lanata Linn. against paracetamol induced hepatotoxicity in rats. Research J Pharm and Tech. 2008;1(4):398-400.

28. Ridruejo E, Cacchione R, Villamil AG, Marciano S, Gadano AC, Mando OG. Imatinib -induced fatal acute liver failure. World J Gastroentrol. 2007;13(48):6608-111.

29. Hedge K, Joshi A. Hepatoprotective effect of Carrisa carandas Linn. Root extract against $\mathrm{CCl}_{4}$ and APAP induced hepatic oxidative stress. Indian J Exp Biol. 2009;47:660-7.

30. Burcham PC, Harman AW. Acetaminophen Toxicity Results in Site-specific Mitochondrial Damage in Isolated Mouse Hepatocytes. J Biol Chem. 1991;266(8):5049-54.

31. Hinson JA, Roberts DW, Jame LP. Mechanisms of Acetaminophen-Induced Liver Necrosis. Handb Exp Pharmacol. 2010;196:369-405.

32. Yana M, Huob Y, Yina S, Hu H. Mechanisms of acetaminophen-induced liver injury and its implications for therapeutic interventions. Redox Biol. 2018;17:274-83.

33. Maheswari C, Maryammal R, Venkatanarayanan R. Hepatoprotective activity of "Orthosiphon stamineus" on liver damage caused by paracetamol in Rats. Jordan J of Biol Sci. 2008;1(3):105-8.

34. Boll M, Weber LW, Becker E, Stampfl A. Mechanism of carbon tetrachlorideinduced hepatotoxicity. Hepatocellular damage by reactive carbon tetrachloride metabolites. Z Naturforsch C J Biosci. 2001;56(7-8):649-59.

35. Sahreen $S$, Khan MR, Khan RA. Hepatoprotective effects of methanol extract of Carissa opaca leaves on $\mathrm{CCl}_{4}$-induced damage in rat. $\mathrm{BMC}$ Complement Altern Med. 2011;11(1):48.

36. Vakati K, Rahman H, Eswaraiah MC, DuttaAM. Evaluation of hepatoprotective activity of ethanolic extract of Aquilaria agallocha leaves (EEAA) against $\mathrm{CCl}_{4}$ induced hepatic damage in rat. Scholars J App Med Sci. 2013;1(1):9-12.

37. Yang J, Li Y, Wang F, Wu C. Hepatoprotective effects of apple polyphenols on $\mathrm{CCl}_{4}$-induced acute liver damage in mice. J Agric Food Chem. 2010;58(10):6525-31.

38. Yang BY, Zhang XY, Guan SW, Hua ZC. Protective effect of procyanidin $B_{2}$ against $\mathrm{CCl}_{4}$-induced acute liver injury in mice. Molecules. 2015;20(7):12250-65.

39. Zou J, Qi F, Ye L, Yao S. Protective Role of grape seed proanthocyanidins against $\mathrm{CCl}_{4}$ induced acute liver injury in mice. Med Sci Monit. 2016;22:880-9.

40. Rasha S, Ismail A, Ashraf A, El-Megeid A, Aly R. Carbon tetrachlorideinduced liver disease in rats: The potential effect of supplement oils with Vitamins E and C on the nutritional status. Ger Med Sci. 2009;7:1612-3174.

41. Kanter M, Coskun O, Budancamanak M. Hepatoprotective effects of Nigella sativa $L$ and Urtica dioica $L$ on lipid peroxidation, antioxidant enzyme systems and liver enzymes in carbon tetrachloride-treated rats. World J Gastroenterol. 2005;11(42):6684-8.

42. Parola M, Leonarduzzi G, Biasi F, Albano M, Biocca E, Poli G, et al. Vitamin E dietary supplementation protects against $\mathrm{CCl}_{4}$-induced chronic liver damage and cirrhosis. Hepatol. 1992;16(4):1014-21.

43. Noori S, Rehman N, Qureshi M, Mahboob T. Reduction of Carbon tetrachloride - induced rat liver injury by coffee and green tea. Pakistan $\mathrm{J}$ of Nutrition. 2009;8(4):452-8.

44. Jeong-Hyeon K, Kye-Taek L. Glycoprotein Isolated from Ulmus davidiana NAKAI Protects against carbon tetrachloride-induced liver injury in the mouse. J Pharmacol Sci. 2006;101(3):205-13.

45. Manna P, Sinha M, Parames CS. Aqueous extract of Terminalia arjuna prevents carbon tetrachloride induced hepatic and renal disorders. BMC Compl and Alter Med. 2006;6(1):33.

46. Samudram P, Rajeshwari $H$, Vasuki $R$, Geetha A, Sathiya MP. Hepatoprotective activity of bi-herbal ethanolic extract on $\mathrm{CCl}_{4}$ induced hepatic hepatic damage in rats. African J of Biochem Res. 2008;2:061-5.

47. Jain PK, Ravichandran V, Agrawal RK. Antioxidant and Free Radical Scavenging Properties of Traditionally Used Three Indian Medicinal Plants. Curr Trends Biotechnol Pharm. 2008;2(4):538-47.

48. Hayes J, Condie L, Borzellec JF. Acute 14 day repeated dosing and 90 days subchronic toxicity studies of $\mathrm{CCl}_{4}$ in CD-1 mice. Fund Appl Toxicol. 1986;7(3):454-63.

49. Kalantari H, Aghel N, Bayati M. Hepatoprotective Effect of Morus alba L. In Carbon Tetrachloride- Induced Hepatotoxicity in Mice. Saudi Pharma J. 2009;17(1):90-4.

50. Etim OE, Akpan EJ, Usoh IF. Hepatotoxicity of carbon tetrachloride: Protective effect of Gongronema latifolium. Pak J Pharm Sci. 2008;21(3):268-74.

51. John NM, Francis EC, Harihara MM. Polyamine Protection against Chemically Induced Hepatotoxicity. Int J Toxicol. 2000;19(6):391-400.

52. Islam A, Mazumder UK, Gupta M, Ghosal S. Synergistic Effects of Geraniin and Rutin in the Antioxidant Properties of Major Lignans in Phyllanthus amarus. Pharmacol. 2008;3:1024-36.

53. Naidu RS, Kumar GS, Gawade SP, Devi K. Protective Effect of LIV-O-G a poly herbal formulation on alcohol- $\mathrm{CCl}_{4}$ and paracetamol induced hepatotoxicity in rats. Pharmacolonline. 2007;3:446-60.

54. Tripathi KD. Essentials of Medical Pharmacology. $7^{\text {th }}$ Edition. Jaypee Brothers Medical Publishers (P) Ltd: Delhi. 2013.

55. Song TY, Yen GC. Protective effects of fermented filtrate from antrodia camphorate in submerged culture against $\mathrm{CCl}_{4}$ - induced hepatic toxicity in rats. J Agric Food Chem. 2003;51(6):1571-7.

56. Brown GT, Kleiner DE. Histopathology of Nonalcoholic Fatty Liver Disease and Nonalcoholic Steatohepatitis. Metabolism. 2016;65(8):1080-6.

57. Weber LWB, Stampfl A. Hepatotoxicty and mechanism of action of haloalkanes: Carbon tetrachloride as a toxicological model. Crit Rev Toxicol. 2003;33(2):105-36.

58. Attia MNT, Ali MA. Hepatoprtotective activity of allicin against Carbon tetrachloride induced hepatic injury in rats. J Biol Sci. 2006;6(3):457-68.

59. Verma N, Singh AP, Amresh G, Sahu PK, Rao CV. Protective effect of ethyl acetate fraction of Rhododendron arboreum flowers against carbon tetrachloride-induced hepatotoxicity in experimental models. Indian J Pharmacol. 2011;43(3):291-5.

60. Yang J, Zhu1 D, Ju B, Jiang X, Hu J. Hepatoprotective effects of Gentianella turkestanerum extracts on acute liver injury induced by carbon tetrachloride in mice. Am J Transl Res. 2017;9(2):569-79.

61. Ativiel RN. Modulations of Hibiscus sabdariffa extract on ethanol-induced hepatotoxicity. Arch of Cur Res Inter. 2017;104:1-6.

62. Balakrishna V, Lakshmi T. Hepatoprotective activity of ethanolic extract of Terminalia chebula fruit against ethanol-induced hepatotoxicity in rats. Asian J Pharm Clin Res. 2017;10(11):55-8

63. Chiang DJ, McCullough AJ. The Impact of Obesity and Metabolic Syndrome on Alcoholic Liver Disease. Clin Liver Dis. 2014;18(1):157-63.

64. Arteel GE. Animal models of alcoholic liver disease. Dig Dis. 2010;28(6):729-36.

65. An L, Wang X, Cederbaum Al. Cytokines in alcoholic liver disease. Arch Toxicol. 2012; 86(9):1337-48.

66. Das SK, Vasudevan DM. Monitoring Oxidative Stress in Patients with NonAlcoholic and Alcoholic Liver Diseases. Indian J Clin Biochem. 2005;20(2):24-8. 
67. Mello T, Ceni E, Surrenti C, Galli A. Alcohol induced hepatic fibrosis: Role of acetaldehyde. Mol Aspects Med. 2008;29(1-2):17-21.

68. Nayanatara AK, Nagaraja HS, Ramaswamy C, Bhagyalakshmi K, Bhat RM, Harini N. Estimation of tissue lipid peroxidation level and organ weight in litters of wistar rats: Exposed to Prenatal Alcohol Ingestion. J of Pharmacy and Biomed Sci. 2009;22:44-7.

69. Ponnappa BC, Rubin E. Modeling alcohol's effects on organs in animal models. Alcohol Res Health. 2000;24(2):93-104.

70. Reuben A. Alcohol and the liver. Curr Opin Gastroenterol. 2008;24:328-38.

71. Alcohol Alert is a Magzine published by US department of Health and Human Service. National Institute of Health, National Institute on Alcohol Abuse and Alcoholism. Alcohol Alert. 2007;72.

72. Popovic M, Snezana JH, Kaurinovic B, Rasic J, Trivic S. Effects of Various Drugs on Alcohol-induced Oxidative Stress in the Liver. Molecules. 2008;13(9):2249-59.

73. Chari S, Gupta M. Status of blood antioxidant enzymes in alcoholic cirrhosis. Indian J Physiol Pharmacol. 2003;47(3):343-6.

74. Kessova I, Cederbaum AI. CYP2E1: Biochemistry, toxicity, regulation and function in ethanol-induced liver injury. Curr Mol Med. 2003;3(6):509-18.

75. Devipriya N, Srinivasan M, Sudheer AR, Menon VP. Effect of ellagic acid, a natural polyphenol, on alcohol-induced prooxidant and antioxidant imbalance: A drug dose dependent study. Singapore Med J. 2007;48(43):311-8.

76. Dahiru D, Obidoa O. Pretreatment of albino rats with aqueous leaf extract of Ziziphus mauritiana protects against alcohol induced liver damage. Tropical J of Pharma Res. 2007;6(2):705-10.

77. Stickel $\mathrm{F}$, Osterreicher $\mathrm{CH}$. The role of genetic polymorphism in alcohol liver disease. Alc Alcohol. 2006;41(3):209-24.

78. Hoak JB, Pastorino JG. Ethanol oxidative stress and cytokine induced liver injury. Alcohol. 2002;27(1):63-8.

79. Pari L, Karthikesan K. Protective role of caffeic acid against alcohol-induced biochemical changes in rats. Fundam Clin Pharmacol. 2007;21(4):355-61.

80. Bird GL, Sheron N, Goka AK, Alexander GJ, Williams RS. Increased plasma tumor necrosis factor in severe alcoholic hepatitis. Ann Intern Med. 1990;112(12):917-20.

81. Hussein JS, Oraby FS, El-Shafey N. Antihepatoxic effect of Garlic and Onion Oils on Ethanol induced liver injury in Rats. J Appl Sci Res. 2007;3(11):1527-33.

82. Simona M, Antonino D, Roberto S, Francesca U, Salvatore P, Francesco P, et al. Pathophysiological, Molecular and Therapeutic Issues of Nonalcoholic Fatty Liver Disease: An Overview. Int J Mol Sci. 2019;20(8):1948.

83. Asma D, Salima A, Samia M, Ghada E, Abubaker E. Dyslipidemia and Fatty Liver Disease in Overweight and Obese Children. J of Obesity. 2018.

84. Kullak-Ublick GA, Andrade RJ, Merz M, End P, Benesic A, Gerbes AL, et al. Drug induced liver injury: Recent advances in diagnosis and risk assessment. Gut. 2017;66(6):1154-64.

85. Atkinson RL. Current status of the field of obesity. Trends Endocrinol Metabol. 2014;25(26):283-4.

86. Kim GW, Lin JE, Blomain ES, Waldman SA. Antiobesity Pharmacotherapy: New Drugs and Emerging Targets. Clin Pharmacol Ther. 2014;95(1):53-66.

87. Panda VS, Kharat PS, Sudhamani S. Antioxidant and hepatoprotective effect of Macrotylomauniflorum seed in antitubercular drug induced liver injury in rats. The J of Phytopharmacol. 2015;4(1):22-9.

88. Iqubal $\mathrm{A}$, Iqubal MK, Haque SE. Experimental hepatotoxicity Inducing agents: A Review. I J of Pharmacol Res. 2016;6(11):325-35.

89. Tweed CD, Wills GH, Crook AM, Dawson R, Diacon AH, Louw CE, et al. Liver toxicity associated with tuberculosis chemotherapy in the RE Mox TB study. BMC Medicine. 2018;16(1):46.

90. Dai Y, Chen SR, Chai L, Zhao J, Wang Y, Wang Y. Overview of Pharmacological Activities of Andrographis paniculata and its Major Compound Andrographolide. Crit Rev Food Sci Nutr. 2018;59(1):S17-29.

91. Pundir R, Singh G, Pandey AA, Saraf SA. Demand of Herbal Hepatoprotective Formulations in Lucknow: A Survey. The Pharma Res. 2009;01(1):23-33.

92. Agrawal B, Das S, Pandey A. Boerhaavia diffusa Linn.: A Review on its Phytochemical and Pharmacological Profile. Asian J of Applied Sci. 2011;4(7):663-84.

93. Ghosh S, Rai SK. Boerhavia diffusa: One plant with many functions. Int J Green Pharm. 2018;12(3):S443.

94. Verma R. A review on hepatoprotective activity of medicinal plants. J Med Plants Stud. 2018;6(1):188-90.
95. Mukhopadhyay G, Kundu S, Sarkar A, Sarkar P, Sengupta R, Kumar C. A review on physicochemical and pharmacological activity of Ecliptaalba. Pharma Innovation. 2018;7(9):78-83.

96. Majee C, Mazumder R, Choudhary AN. Medicinal Plants with Anti-Ulcer and Hepatoprotective Activity: A Review. I J Pharmaceu Sci Res. 2019;10(1):1-11.

97. Ray A, Chaudhuri SR, Majumdar B, Bandyopadhyay SK. Antioxidant activity of ethanol extract of rhizome of Picrorhiza kurroa on indomethacin induced gastric ulcer during healing. I J Clinic Biochem. 2002;17(2):44-51.

98. Kumar RA, Rajkumar V, Kalaivani T, Guha G, Mathew L. Antioxidant and anti-neoplastic activities of Picrorhiza kurroa extracts. Food and Chemical Toxicol. 2010;49(2):363-9.

99. Kumar M, Mukhtar HM, Goyal R, Nain VS. Enhancement of Hepatoprotective Effect of Herbal Formulation (F1) on Carbon tetrachloride and Ethanol Induced Liver Toxicity in Albino Rats. J of Drug Discovery and Therapeu. 2014;2(19):30-9.

100. Joshi SG, Oleaceae. Medicinal Plants. Oxford and IBH Publishing Co. Pvt. Ltd, New Delhi. 2000;298-300.

101. Verma N, Singh J. Evaluation of Hepatoprotective Activity of Tephrosia purpurea Linn. Stem. IE Applied Scienti Res J. 2017;2(7):1-2.

102. Gora RH, Baxla SL, Kerketta P, Patnaik S, Roy BK. Hepatoprotective activity of Tephrosia purpurea against arsenic induced toxicity in rats. Indian J Pharmacol. 2014;46(2):197-200.

103. Shah R, Parmar S, Bhatt P, Chanda S. Evaluation of Hepatoprotective activity of Ethyl Acetate Fraction of Tephrosia purpurea. Pharmacologyonline. 2011;3:188-94.

104. Jain A, Singhai AK, Dixit VK. A comparative study of ethanol extract of leaves of Tephrosia purpurea pers and the flavonoid isolated for hepatoprotective activity. Indian J Pharm Sci. 2006;68(6):740-3.

105. Adeneye AA, Benebo AS, Agbaje EO. Protective effect of the Aqueous Leaf and seed Extract of Phyllanthus amarus on Alcohol- induced hepatotoxity in rats. West African J Pharmacol Drug Res. 2006;22:42-50.

106. Kassuya CA, Silerstre AA, Rehder V, Calixto JB. Anti allodynic and antioedematogeni properties of the lignan from Phyllanthus amarus in models of persistent inflammatory and neuropathic pain. Eur $\mathrm{J}$ Pharm. 2003;478(2-3):145-53.

107. Hassan MA, Masud IA. An overview of the hepatoprotective potentials of Phyllanthus amarus. J of Pharmacog and Phytochem. 2018;7(2):2777-82.

108. Pramyothin P, Ngamtin C, Poungshompoo S, Chaichantipyuth C. Hepatoprotective activity of Phyllanthus amarus Schum. et. Thonn. extract in ethanol treated rats: In vitro and in vivo studies. J Ethnopharmacol. 2007;114(2):169-73.

109. Kumaresan R, Sneeha V, Elango V. A Study on Hepatoprotective Activity of Mimosa pudica in Albino Rats. I J of Pharmacognosy and Phytochem Res. 2015;7(2):337-9.

110. Balakrishnan N, Bhasker VH, Jayakar B, Sangameswaran B. Antibacterial activity of Mimosa pudica, Aegle marmelos and Sida cordifolia. Pharmacog Magazine. 2006;2(7):198-9.

111. Rajendran RS, Hemalatha $\mathrm{K}$, Akasakalai $\mathrm{CH}$, Madhu $\mathrm{K}$, Bavan S, Vittal R. Hepatoprotective activity of Mimosa pudica leaves against Carbon tetrachloride induced toxicity. J Nat Prod. 2009;2:116-22.

112. Patra A, Jha S, Murthy PN, Roy D, Sahu AN. Analgesic and antimotility activities of Hygrophila spinosa T. Anders. Pharmacology Online. 2008;2:821-8.

113. Kshirsagar AD, Ingale G, Vyawahare NS, Thorve VS. Hygrophila spinosa: A comprehensive review. Pharmacogn Rev. 2010;4(8):167-71.

114. Kumar M, Ravindu S, Kumar M, Selvan SR, Saharan B, Kumar A. Protective effect of Adhatoda vasica Nees against radiation-induced damage at cellular, biochemical and chromosomal levels in Swiss albino mice. Evid Based Complement Alternat Med. 2007;4(3):343-50.

115. Hossain MT, Hoq MO. Therapeutic use of Adhatoda vasica. Asian J Med Biol Res. 2016;2(2):156-63.

116. Baishnab S, Satija V, Das S. Hepatoprotective Effect of Adhatoda vasica Leaves Extract Against Paracetamol Induced Hepatic Damage in Rats. The Internet J of Pharmacol. 2013;12(1):1.

117. Chaudhari SR, Chavan MJ, Gaud RS. Phytochemical and Pharmacological research on the roots of Capparis sepiaria. Indian J Pharmaceut Sci. 2004;66(4):454-7.

118. ThirumalaiKumaran R, Uma MCR. Evaluation of Hepatoprotective activity of Capparis sepiaria leaves. International J of Biomedical Res. 2011;2(3):204-12. 
119. Goyal M, Pareek A, Nagori BP, Sasmal D. Aerva lanata: A review on phytochemistry and pharmacological aspects. Pharmacogn Rev. 2011;5(10):195-8.

120. Payal C, Gurlaganjeet K, Davinder K, Gagan S, Amit C, Dhawan RK. A Review on Phytochemistry and Biological Activities of Aerva. Med Aromat Plants. 2015;4(2):1-4.

121. Athira P, Sreesha NN. Pharmacognostic Review of Medicinal Plant Aerva lanata. J Pharm Sciand Res. 2017;9(9):1420-3.

122. Jain R, Sharma A, Gupta S, Sarethy IP, Gabrani R. Solanum nigrum: Current Perspectives on Therapeutic Properties. Alternative Medicine Review: J Of Clinic Therap. 2011;16(1):78-85.

123. Raju K, Anbuganapathi G, Gokulakrishnan V, Rajkapoor B, Jayakar B, Manian S. Effect of dried fruits of Solanum nigrum Linn. Against $\mathrm{CCl}_{4}$-induced hepatic damage in rats. Biol Pharma Bull. 2003;26(11):1618-9.

124. Elshater A, Salman MAA, Mohamed SA. The hepato-ameliorating effect of Solanum nigrum against $\mathrm{CCl}_{4}$ induced liver toxicity in albino rats. Egypt Acad J Biolog Sci. 2013;5(1):59-66.

125. Krithika R, Varma RJ. Solanum nigrum confers protection against $\mathrm{CCl}_{4}$ induced experimental hepatotoxicity by increasing hepatic protein synthesis and regulation of energy metabolism. I. J of Phytomed and Phytotherapy. Clinical Phytoscience. 2019;5(1):1.

126. Mishra G, Sinha R, Verma N, Khosa RL, Garg VK, Singh P. Hepatoprotective activity of alcoholic and aqueous extracts of Wedelia chinensis. Pharmacology Online. 2009;1:345-56.

127. Verma N, Khosa RL, Kumar V. Wound healing activity of Wedelia chinensis leaves. Pharmacology Online. 2008;2(3):139-45.

128. Jalal AS, Selvakumar S, Nallathambi R, Jeevaprakash G, Dheivanai SL, Senthilvelan S. Hepatoprotective activity of Wedella chinesis against Carbon-Tetrachloride induced liver damage in rats. I J of Phytopharmacol. 2012;3:121-5

129. Lin SC, Lin CC, Lin YH, Shyuu SJ. Hepatoprotective effects of Taiwan folk medicine: Wedelia chinensison three hepatotoxin-induced hepatotoxicity. Am J Chin Med. 1994;22(2):155-68.

130. Devi B, Sharma N, Kumar D, Jeet K. Morus alba Linn: A Phytopharmacological Review. Int J Pharm Pharm Sci. 2013;5(2):14-8.

131. Hogade MG, Patil KS, Wadkar GH, Mathapati SS, Dhumal PB. Hepatoprotective activity of Morus alba (Linn.) leaves extract against carbon tetrachloride induced hepatotoxicity in rats. African $\mathrm{Jl}$ of Pharmacy and Pharmacol. 2010;4(10):731-4.

132. Abdullah N, Saat MN, Hasan HA, Budin SB, Kamaralazaman S. Protective effect of the ethanol extract of Zingiber officinale roscoe on paracetamol induced hepatotoxicity in rats. J Sains Keshtan Malasia. 2004;2(2):85-95.

133. Kikusaki $\mathrm{H}$, Nakatani $\mathrm{N}$. Antioxidant effect of some ginger constituents. J Food Sci. 1993;58(6):1407-10.

134. Motawi TK, Hamed MA, Shabana MH, Hashem RM, AboulNaser AF. Zingiber officinale acts as a nutraceutical agent against liver fibrosis. Nutrition and Metabolism. 2011;8(1):40.

135. Esfandiary E, Abdolali Z, Omranifard V, Ghanadian M, Bagherian-Sararoud R, Karimipour $\mathrm{M}$, et al. Novel effects of Rosa damascena extract on patients with neurocognitive disorder and depression: A clinical trial study. Int J Prev Med. 2018;9:57.

136. Saxena M, Shakya AK, Sharma N, Shrivastava S, Shukla S. Therapeutic Efficacy of Rosa damascena Mill. on Acetaminophen-Induced Oxidative Stress in Albino Rats. J Environ Pathol Toxicol Oncol. 2012;31(3):193-201.

137. Yassa N, Masoomi F, Rohani RSE, Hadjiakhoondi A. Chemical Composition and Antioxidant Activity of the Extract and Essential oil of Rosa damascena from Iran. Population of Guilan. Daru. 2009;17(3):175-80.

138. Kumar DR, George VC, Suresh PK, Kumar RA. Cancer-specific chemoprevention and anti-metastatic potentials of Rheum emodi rhizome ethyl acetate extracts and identification of active principles through HPLC and GC-MS analysis. Pak J Pharm Sci. 2015;28(1):83-93.

139. Akhtar MS, Amin M, Ahmad MA. Hepatoprotective Effect of Rheum emodi Roots (Revandchini) and Akseer-e-Jigar against Paracetamol-induced Hepatotoxicity in Rats. Ethnobotanical Leaflets. 2009;13:310-5.

140. Akhtar MS, Habib A, Ali A, Bashir S. Isolation, identification and in vivo evaluation of flavonoid fractions of chloroform/methanol extracts of Rheum emodi roots for their hepatoprotective activity in Wistar rats. Int J Nutr Pharmacol Neurol Dis. 2016;6(1):28-34
141. Omar BR, El-Naa MM, Zaghloul SS, Omar MM. Profile of bioactive compounds in Nymphaea alba L. leaves growing in Egypt: Hepatoprotective, antioxidant and anti-inflammatory activity. BMC Complement Altern Med. 2017;17(1):52.

142. Bakr RO, El-Naa MM, Zaghloul SS, Omar MM. Profile of bioactive compounds in Nymphaea alba L. leaves growing in Egypt: Hepatoprotective, antioxidant and anti-inflammatory activity. BMC Complement Altern Med. 2017;17(1):52.

143. Madhusudhanan N, Lakshmi T, Kumar G, Ramakrishanan KV, Roy A, Geetha R. In vitro antioxidant and free radical scavenging activity of aqueous and ethanolic flower extract of Nymphaea alba. Int J Drug Dev Res. 2011;3(3):252-8.

144. Nasiruddin M, Khan IA, Arif SH. Ameliorative Potentials of Nymphaea alba on Hepatotoxicity and Oxidative Damage Induced by Chronic Exposure to Isoniazid in Rats. Int Res J Pharm. 2019;10(7):60-4.

145. Jesurun J, Jagadeesh S, Ganesan S, Rao V, Eerike M. Anti-inflammatory activity of ethanolic extract of Nymphaea alba flower in swiss albino mice. Int J Med Res Heal Sci. 2013;2(2):474-8.

146. Khalid A, Shahid S, Khan SA, Kanwal S, Yaqoob A, Rasool ZG. Antioxidant activity and hepatoprotective effect of Cichorium intybus (Kasni) seed extract against carbon tetrachloride-induced liver toxicity in rats. Trop J Pharm Res. 2018;17(18):1531-8.

147. Li G, Gao H, Huang J, Lu J, Gu J, Wang J. Hepatoprotective effect of Cichorium intybus L. a traditional Uighur medicine, against carbon tetrachloride-induced hepatic fibrosis in rats. World J Gastroenterol. 2014;20(16):4753-60.

148. Elgengaihi S, Mossa AT, Refaie AA, Aboubaker D. Hepatoprotective Efficacy of Cichorium intybus L. Extract Against Carbon Tetrachloride-induced Liver Damage in Rats. J Diet Suppl. 2016;13(5):570-84.

149. Rokhsana R, Hassan S, Reza K, Hadi R. Hepatoprotective Effects of Cichorium intybus against Paracetamol Induced Hepatotoxicity in Broiler. J World Poult Res. 2018;8(2):25-30.

150. Bischoff TA, Kelley CJ, Karchesy Y, Laurantos M, Nguyen-Dinh P, Arefi AG. Antimalarial activity of Lactucin and Lactucopicrin: Sesquiterpene lactones isolated from Cichorium intybus L. J of Ethnopharmacol. 2004;95(2):455-7.

151. Pieroni A. Medicinal plants and food medicines in the folk traditions of the upper Lucca Province, Italy. J of Ethnopharmacol. 2000;70(3):235-73.

152. Papackova Z, Heczkova M, Dankova H, Sticova E, Lodererova A, Bartonova L, et al. Silymarin prevents acetaminophen-induced hepatotoxicity in mice. PLoS One. 2018;13(1):e0191353.

153. Muriel P, Garciapina T, Perez-Alvarez V, Mourelle M. Silymarin protects against paracetamol-induced lipid peroxidation and liver damage. J Appl Toxicol. 1992;12(6):439-42.

154. Wang M, Grange LL, Tao J. Hepatoprotective properties of Silybum marianum herbal formulation on ethanol induced liver damage. Fitoterpia. 1996;67:167-71.

155. Dixit N, Baboota S, Kohli K, Ahmad S, Ali J. Silymarin: A review of pharmacological aspects and bioavailability enhancement approaches. Indian J Pharmacol. 2007;39(4):172-9.

156. Haddad Y, Diane V, Antoine B, Haddad PS. Antioxidant and Hepatoprotective Effects of Silibinin in a Rat Model of Nonalcoholic Steatohepatitis. Evid Based Complement Alternat Med. 2011;1-10.

157. Sreedevi CD, Latha PG, Ancy P, Suja SR, Shyamal S, Shine VJ, et al. Hepatoprotective studies on Sida acuta Burm. J Ethnopharmacol. 2009;124(2):171-5.

158. Tiwari BK, Khosa RL. Hepatoprotective and antioxidant effect of Sphaeranthus indicus against acetaminophen-induced hepatotoxicity in rats. J Pharm Sci and Res. 2009;1(2):26-30.

159. Rajesh S, Rajkapoor B, Kumar R, Raju K. Effect of Clausena dentata (Willd.) M. Roem. Against Paracetamol Induced Hepatotoxicity In Rats. Pak J Pharm Sci. 2009;22(1):90-3.

160. Dawada S, Varsha ZV, Dinesh DD, Shital PS. Hepatoprotective Activity of Cassia fistula root against Carbon tetrachloride-Induced Hepatic Injury in rats (Wistar). I J of Pharma Sci and Res. 2012;3(4):368-78.

161. Masundaram A, Ramadoss K, Vadivel V, Balasubramanian D, Muthu R. Evaulation of hepatoprotective activity of Kyllinga nemoralis (Huch and Dalz) rhizomes. J Ethnopharmacol. 2009;127(2):555-7.

162. Ranawat L, Bhatt J, Patel J. Hepatoprotective activity of ethanolic extracts of bark of Zanthoxylum armatum dc in $\mathrm{CCl}_{4}$ induced hepatic damage in rats. J Ethnopharmacol. 2009;127(3):777-80. 
163. Kumar SS, Kumar BR, Mohan GK. Trichosanthes cucumerina on carbon tetrachloride induced liver damage in rats. J Ethnopharmacol. 2009;123(2):347-50

164. Upur H, Amat N, Blazekovic B, Talip A. Protective effect of Cichorium glandulosum root extract on carbon tetrachloride-induced and galactosamineinduced hepatotoxicity in mice. Food Chem Toxicol. 2009;47(8):2022-30.

165. Hegde K, Joshi AB. Hepatoprotective effect of Carissa crandas Linn root extract against $\mathrm{CCl}_{4}$ and paracetamol induced hepatic oxidative stress. Indian $\mathrm{J}$ of Experimental Biology. 2009;47:660-7.

166. Usha K, Kasturi GM, Hemlatha P. Hepatoprotective effect of Hygrophila spinosa and Cassia occidentalis on carbon tetrachloride induced liver damage in experimental rats. Indian J Cli Biochem. 2007;22(2):132-5.

167. Pari L, Suresh A. Effect of grape (Vitis vinifera L.) leaf extract on alcohol induced oxidative stress in rats. Food Chem Toxicol. 2008;46(5):1627-34.

168. Maruthappan V, Sakthi KS. Hepatoprotective effect of Azadirachta indica (Neem) leaves against alcohol induced liver injury in albino rats. J Pharma Res. 2009;2(4):655-9.

169. Reddy VD, Pannuru P, Maturu P, Varadacharyulu A. Modulatory role of Emblica officinalis against alcohol induced biochemical and biophysical changes in rat erythrocyte membranes. Food Chem Toxicol. 2009;47(8):1958-60.

170. Maiti K, Mukherjee K, Murugan V, Saha BP, Mukherjee PK. Enhancing bioavailability and hepatoprotective activity of andrographolide from Andrographis paniculata, a well-known medicinal food, through its herbosome. J Sci Food Agric. 2010;90(1):43-51.

171. Vargas-Mendoza N, Madrigal-Santillán E, Morales-González A, EsquivelSoto J, Esquivel-Chirino C, González-Rubio MG, et al. Hepatoprotective effect of Silymarin. World J Hepatol. 2014;6(3):144-9.

172. Verma PC, Basu V, Gupta V, Saxena G, Rahman LU. Pharmacology and chemistry of a potent hepatoprotective compound Picroliv isolated from the roots and rhizomes of Picrorhiza kurroa royle ex benth. (kutki). Curr Pharm Biotechnol. 2009;10(6):641-9.

173. Chigurupati H, Auddy B, Biyani M, Stohs SJ. Hepatoprotective Effects of a Proprietary Glycyrrhizin Product during Alcohol Consumption: A Randomized, Double-Blind, Placebo-Controlled, Crossover Study. Phytother Res. 2016;30(12):1943-195

174. Lian LH, Jin X, Wu YL, Cai XF, Lee JJ, Nan JX. Hepatoprotective effects of Sedum sarmentosum on D-galactosamine/lipopolysaccharide-induced murine fulminant hepatic failure. J Pharmacol Sci. 2010;114(2):147-57.

175. Gutiérrez-Rebolledo GA, Siordia-Reyes AG, Meckes-Fischer M, JiménezArellanes A. Hepatoprotective properties of oleanolic and ursolic acids in antitubercular drug-induced liver damage. Asian Pac J Trop Med. 2016;9(7):644-51.

176. Kyung EJ, Kim HB, Hwang ES, Lee S, Choi BK, Kim JW, et al. Evaluation of Hepatoprotective Effect of Curcumin on Liver Cirrhosis Using a Combination of Biochemical Analysis and Magnetic Resonance-Based Electrical Conductivity Imaging. Mediators Inflamm. 2018;5491797.

177. Lee $\mathrm{BH}$, Huang YY, Duh PD, Wu SC. Hepatoprotection of emodin and Polygonum multiflorum against $\mathrm{CCl}_{4}$-induced liver injury. Pharm Biol. 2012;50(3):351-9.

178. Qureshi SA, Jahan M, Lateef T, Ahmed D, Rais S, Azmi MB. Presence of gallic acid and rutin improve the hepatoprotective strength of Withania coagulans. Pak J Pharm Sci. 2019;32:301-8.

179. Mathur N, Katare PD, Aeri V. Cichorium intybus Linn: It's Role in Hepatoprotection. I J of Pharmacog and Phytochem I Res. 2014;6:499-505.

180. Jaswal A, Sinha N, Monika M, Shrivastava S, Shukla S. Therapeutic potential of thymoquinone against anti-tuberculosis drugs induced liver damage. Environtoxicoland Pharmacol. 2013;36(1):779-86.

181. Huanga $\mathrm{C}$, Tung $\mathrm{YT}$, Cheng $\mathrm{KC}, \mathrm{Wu} \mathrm{JH}$. Phytocompounds from Vitis kelungensis stem prevent carbon tetrachloride-induced acute liver injury in mice. Food Chem. 2011;125(2):726-31.

182. Mirzaee F, Hosseini A, Jouybari HB, Davoodi A, Azadbakht M. Medicinal, biological and phytochemical properties of Gentiana species. J Tradit Complement Med. 2017;7(4):400-8.

183. Abdel-Azeem AS, Hegazy AM, Ibrahim KS, Farrag AR, El-Sayed EM. Hepatoprotective, antioxidant and ameliorative effects of ginger (Zingiber officinale Roscoe) and Vitamin E in acetaminophen treated rats. J Diet Suppl. 2013;10(3):195-209.

184. Shrivastava S. S-Allyl-Cysteines Reduce Amelioration of Aluminum Induced Toxicity in Rats. American J of Biochem and Biotechnology. 2011;7(2):74-83.

185. Yoshikawa M, Xu F, Morikawa T, Ninomiya K, Matsuda H. Anastatins A and B, new skeletal flavonoids with hepatoprotective activities from the desert plant Anastatica hierochuntica. Bioorg Med Chem Lett. 2003;13(6):1045-9.

186. Zheng QS, Sun XL, Xu B, Li G, Song M. Mechanisms of apigenin-7-glucoside as a hepatoprotective agent. Biomed Environ Sci. 2005;18(1):65-70.

187. Afifi NA, Ibrahim MA, Galal MK. Hepatoprotective influence of quercetin and ellagic acid on thioacetamide-induced hepatotoxicity in rats. Can J Physiol Pharmacol. 2018;96(6):624-9.

188. Forouzan F, Azita H, Payman A. Resveratrol and liver: A systematic review. J Res Med Sci. 2015;20(8):797-810.

189. Fragoso RL, Ayala AE, García VGF, Esparza RJ. Genistein Produces Hepatoprotection through Modulating EGFR Expression and Phosphorylation in Experimental Fibrosis. J Liver. 2016,5(196):2167-889.

190. Shanmugam B, Shanmugam KR, Ravi S, Subbaiah GV, Ramakrishana C, Mallikarjuna K, et al. Exploratory Studies of (-)-Epicatechin, a Bioactive Compound of Phyllanthus niruri, on the Antioxidant Enzymes and Oxidative Stress Markers in D-galactosamine-induced Hepatitis in Rats: A Study with Reference to Clinical Prospective. Pharmacogn Mag. 2017;13(Suppl 1):S56-62.

\section{SUMMARY}

- The liver is the central organ for the metabolism and elimination of toxic agents from the human body.

- An imbalance between the antioxidant defence system and Oxidative stress (free radical species) leads to hepatic dysfunction.

- Hepatotoxicity is related to the toxic metabolites, over dose of drugs and pathogenic organisms.

- $\mathrm{CCl}_{4}, \mathrm{APAP}$ and Alcohol are the experimental toxic agents metabolised by the liver CYP-450 enzymes system. They are widely used to hepatoprotective studies.

- Hepatotoxicity is characterized by the alteration of liver makers enzymes and histopathological changes in hepatocytes cells.

- Traditional medicinal plants are rich source of active phytochemicals that act as a therapeutic drug against hepatic disease/hepatotoxicity.

- Some hepatoprotective phytochemicals such as Andrographolide, Silybin, Picroside, Glycyrrhizin, Curcumin, Emodin, Gallic acid, Esculetin, Thymoquinone, Gingerol, S-Allyl-L-Cysteine, Apigenin, Quercetin, Resveratrol, Genistein, Epicatechins gallate etc. have been reported to offer promising hepatoprotection.

- By standardizing and evaluating the plant derived active phytochemicals can offer promising remedies in the healthcare system to treat human diseases in the future.

- Ensuring the safety, quality, standardisation and effectiveness of medicinal plants and herbal medicine are the key issue before the scientific communities and pharmaceutical companies. 


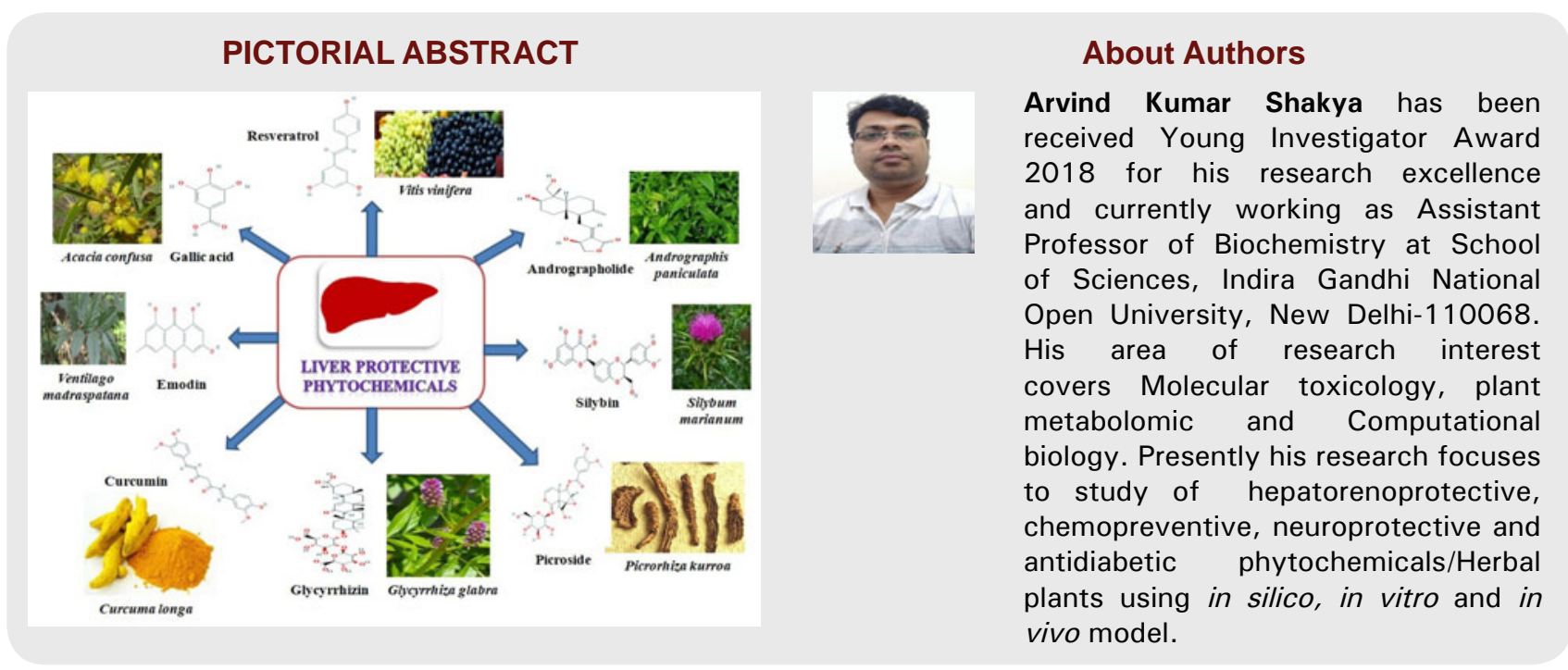

Cite this article: Shakya AK. Drug-induced Hepatotoxicity and Hepatoprotective Medicinal Plants: A Review. Indian $\mathrm{J}$ of Pharmaceutical Education and Research. 2020;54(2):234-50. 